\title{
HOW ECONOMIC SECURITY CHANGES DURING RETIREMENT
}

\author{
Barbara A. Butrica* \\ CRR WP 2007-6 \\ Released: February 2007 \\ Draft Submitted: February 2007 \\ Center for Retirement Research at Boston College \\ Hovey House \\ 140 Commonwealth Avenue \\ Chestnut Hill, MA 02467 \\ Tel: 617-552-1762 Fax: 617-552-0191 \\ http://www.bc.edu/crr
}

\begin{abstract}
* Barbara A. Butrica is a senior research associate at the Urban Institute. The research reported herein was performed pursuant to a grant from the U.S. Social Security Administration (SSA) funded as part of the Retirement Research Consortium. The findings and conclusions are solely those of the author and do not represent the views of SSA, any agency of the Federal Government, the Urban Institute, or Boston College. The author is grateful to Matt Resseger for research assistance.
\end{abstract}

(C) 2007, by Barbara Butrica. All rights reserved. Short sections of text, not to exceed two paragraphs, may be quoted without explicit permission provided that full credit, including (C) notice, is given to the source. 


\title{
About the Center for Retirement Research
}

The Center for Retirement Research at Boston College, part of a consortium that includes parallel centers at the University of Michigan and the National Bureau of Economic Research, was established in 1998 through a grant from the Social Security Administration. The Center's mission is to produce first-class research and forge a strong link between the academic community and decision makers in the public and private sectors around an issue of critical importance to the nation's future. To achieve this mission, the Center sponsors a wide variety of research projects, transmits new findings to a broad audience, trains new scholars, and broadens access to valuable data sources.

\author{
Center for Retirement Research at Boston College \\ Hovey House \\ 140 Commonwealth Avenue \\ Chestnut Hill, MA 02467 \\ phone: 617-552-1762 fax: 617-552-0191 \\ e-mail: crr@bc.edu \\ www.bc.edu/crr
}

\author{
Affiliated Institutions: \\ American Enterprise Institute \\ The Brookings Institution \\ Center for Strategic and International Studies \\ Massachusetts Institute of Technology \\ Syracuse University \\ Urban Institute
}




\begin{abstract}
Most studies of retirement well-being have focused on outcomes for relatively young retirees. Few studies have considered how retirement security changes as older Americans age. Following older adults from age 67 (when most have stopped working) to age 80 , this study uses projections of wealth and income to assess how their economic security changes during retirement. Results indicate that typical older adults experience a decline in retirement wealth and income between ages 67 and 80. More than two-fifths of retirees will have significantly less income at age 80 than they did at age 67, with the median decline in income being $\$ 16,000$ for current retirees and $\$ 23,000$ for boomers. Some older adults, however, will be better off later in retirement. Approximately twofifths of retirees will have significantly more income at age 80 than they did at age 67, with the median increase in income being $\$ 14,000$ for current retirees and $\$ 17,000$ for boomers. At least some of the change in economic well-being during retirement is related to changes in marital status, health status, living arrangements, and work status.
\end{abstract}




\section{INTRODUCTION}

As workers retire at increasingly younger ages and life expectancies continue to rise, older Americans are spending more time in retirement than ever before. For this reason, much attention has been placed on the importance of saving for retirement. In many cases, however, the context for evaluating retirement preparedness is at retirement—a point in time-rather than throughout retirement — which may be years or even decades. That is, most studies of retirement well-being have focused on outcomes at relatively young ages (Butrica, Iams, and Smith 2003; Butrica and Uccello 2004; Moore and Mitchell 2000; Gustman and Steinmeier 1999). Few studies have considered how economic security changes as retirees grow older. Although the wealth accumulated at retirement may be sufficient to maintain living standards initially, it may not be enough to support consumption throughout retirement. Life-changing events during retirement, such as the onset of poor health or the death of a spouse, can cause unexpected shocks to wealth and income. In addition, private pension income can erode over time with inflation, because most plans (unlike Social Security) do not peg benefits to changes in the cost of living.

This study examines how economic security is expected to change for current and future retirees as they grow older. The analysis uses the Social Security Administration's Model of Income in the Near Term (MINT) to follow older adults from age 67 (when most have stopped working) to age 80. It considers how the level and composition of their wealth and income change during this time period. It also identifies older adults whose economic situations have improved and those whose situations have worsened using a number of different thresholds for what is considered sufficient for living a comfortable retirement. The study concludes by measuring the extent to which key life-changing events relate to retirement well-being at ages 67 and 80 .

The results show that typical older adults experience a decline in retirement wealth and income between ages 67 and 80 . As a result, their standard of living in retirement-as measured by replacement rates - is projected to fall. Also, the proportion with retirement incomes less than 45 percent of the national average wage is projected to increase. More than two-fifths of retirees will have significantly less income at age 80 than they did at age 67. However, another two-fifths of retirees will receive significantly more income at age 80 than at age 67 . At least 
some of the change in economic well-being during retirement is related to changes in marital status, health status, living arrangements, and work status.

\section{PREVIOUS LITERATURE}

A number of studies have analyzed the economic security of retirees. Many of them suggest that most current retirees are doing well (Gustman and Steinmeier 1999; Haveman et al. 2003) and future retirees are likely to receive at least as much income as previous generations (Butrica and Uccello 2004; Butrica, Iams, and Smith 2003; Smith 2002). These studies have generally focused on outcomes at relatively young retirement ages.

Perhaps due to data limitations, relatively fewer studies have followed older adults throughout their retirement to see how their economic resources change as they grow older. One study by Haveman, Holden, Wolfe, and Romanov (2004), uses the Social Security Administration's New Beneficiary Data System to examine changes in the adequacy of retirement savings during the first 10 years of retirement. The authors generally find that retirees have adequate resources both at the time they first began collecting Social Security benefits and 10 years later. However, their conclusions are based on a sample of adults born between 1910 and 1920 who retired in 1982. Given important ongoing changes in the demographics, educational attainment, and economic resources of older adults, as well as rapid increases in the labor supply of married women, these findings may not generalize to current and future generations of retired Americans.

A more recent study by Coile and Milligan (2006) uses the Health and Retirement Study (HRS) to examine how asset holdings change after retirement. The authors find that health shocks and widowhood play a large role in explaining why the share of wealth in housing declines and the share of wealth in bank accounts and Certificates of Deposits increase as retirees age. While the results of this study shed light on how older households make their portfolio decisions and reallocate their assets during retirement, they say less about how economic security changes during retirement.

Also using the HRS, a study by Johnson, Mermin, and Uccello (2006) finds that 87 percent of adults ages 51-61 and 75 percent of adults age 70 and older experience or have a spouse that experiences at least one negative event over about 10 years. Even after controlling

for demographic characteristics and baseline health conditions, the authors find that adults ages 
51-61 who developed work disabilities or were laid off and adults age 70 or older who entered a nursing home or became divorced experienced significant declines in wealth over the period. The focus of their study is on shocks experienced during retirement and how they impact household wealth. For that reason, the authors did not consider how the importance of various wealth and income sources change over time, nor did they examine how the adequacy of retirement resources changes over time.

This study builds on previous research in a number of ways. First, it analyzes economic security throughout retirement, rather than just at the start of retirement. Second, it presents results for more recent retirees and future retirees. Third, it uses a comprehensive measure of retirement resources to capture total family wealth and income, to examine how each component's share of income changes over time, and to assess the adequacy of retirement resources.

\section{METHODOLOGY}

The analysis is based on projections of the major sources of retirement wealth and income from the Social Security Administration's Model of Income in the Near Term (MINT). MINT starts with data from the U.S. Census Bureau's Survey of Income and Program Participation (SIPP) matched to the Social Security Administration's administrative records on earnings, benefits, and mortality. MINT then projects each individual's marital status changes, mortality, entry to and exit from Social Security disability insurance (DI) rolls, and age of first receipt of Social Security retirement benefits. It also projects sources of family wealth and income. ${ }^{1}$ (For more information see Smith, Cashin, and Favreault 2005).

\footnotetext{
${ }^{1}$ The projections in this study are based on MINTEX, which includes a number of improvements over previous versions of MINT. First, MINTEX extends the MINT data file to capture additional birth cohorts and their retirement prospects. MINT was originally designed to project the distribution of retirement income in 2020 and therefore included only individuals born between 1926 and 1965. MINTEX projects retirement income out to 2099 and includes individuals born between 1926 and 2017. Second, MINTEX adjusts the baseline wealth in the MINT data file to more closely match wealth in the Survey of Consumer Finances (SCF) — commonly regarded as one of the best sources of wealth data. Third, MINTEX updates the MINT macroeconomic assumptions. MINT uses the Social Security Administration's Office of the Chief Actuary (OCACT) projections from the intermediate cost scenario in the 2002 OASDI Trustees Report of disability prevalence, mortality through age 65, the growth of average economy-wide wages, and the consumer price index (CPI). MINTEX uses economic assumptions from the 2004 OASDI Trustees Report. MINTEX also includes updates to the defined contribution thresholds.
} 
This study assesses the long-term economic prospects of retirees by comparing their retirement resources and well-being at age 67, when most have stopped working, with their outcomes at age 80. It uses several measures to assess retirement security, including retirement wealth, income, replacement rates, and poverty rates. The measure of family wealth includes financial assets and housing equity, as well as Social Security and private pensions. Social Security and pension wealth are computed as the present discounted value (PDV) of the future stream of Social Security and pension benefits from ages 67 or 80 until the projected age of death. The computations assume a real interest rate of 2 percent. Measuring household wealth broadly to include pension wealth and Social Security wealth is particularly important for retirees.

In addition to the income that could be generated from wealth at retirement, the analysis includes other income resources at ages 67 and 80 such as earnings, Supplemental Security Income (SSI), and income from co-resident family members. These sources of retirement income are likely to be especially important to retirees. Thus the measure of family income includes income from assets, imputed rental income, Social Security benefits, pension income, earnings, SSI, and co-resident income. ${ }^{2}$

This study evaluates the adequacy of retirement resources using a number of different yardsticks. First, it analyzes income replacement rates to compare the standard of living obtainable in retirement to the level achieved during the working years. Replacement rates are the ratio of per capita family income at ages 67 or 80 to average shared earnings between ages 22 and 62, where shared earnings is half the total earnings of the couple in the years when the individual is married and his or her own earnings in years when single. Replacement rates do not account for imputed rent and co-resident income since these income flows, unlike Social Security and pensions (for example), are not derived from pre-retirement earnings.

Financial planners often recommend that retirees have enough income to replace 70 to 80 percent of their pre-retirement earnings. For this reason, this study also considers the share of retirees whose replacement rates are less than 75 and 50 percent. Based on the financial

\footnotetext{
${ }^{2}$ Imputed rental income is 3.0 percent of the difference between the house value and the remaining mortgage principal. There is debate over whether to include housing in income measures and replacement rates. Proponents argue that homeowners with identical financial resources as renters are better off because they don't have to pay additional income for housing. Critics argue that only actual income flows should be included. Although imputed rent is included in the income measure used to describe the overall levels and composition of family income, it is not included in the income measure used to determine replacement rates and poverty rates.
} 
planning literature, a 50 percent replacement rate represents a serious shortfall that could create economic challenges and necessitate lifestyle adjustments.

Second, this study examines poverty rates to assess whether retirees' incomes will be high enough to support a basic standard of living. It calculates poverty rates using the official poverty thresholds of the U.S. Census Bureau. These thresholds vary with family size and age and increase annually with increases in prices as measured by the Consumer Price Index (CPI). The analysis uses the 65-and-over poverty threshold, which assumes that married couples need about 1.26 times the income that single adults need to live equally well. Like the U.S. Census Bureau, it does not include imputed rent in the income measure used to determine poverty rates.

Poverty is an absolute concept because individuals are considered poor if they have family incomes below an absolute minimum level - the official poverty thresholds. Alternatively, one might think it important to preserve the relative economic position of individuals. To this end, this study also examines the share of retirees with per capita income less than 45 percent of the national average wage-the definition of low-wage earners used by the Social Security Administration's Office of the Chief Actuary (OCACT).

Finally, this study calculates the share of retirees whose retirement resources increase and decrease as they age. Those who are "better off" experience an increase in wealth, income, or replacement rates of more than 5 percent between ages 67 and 80. In contrast, retirees are "worse off" if their wealth, income, or replacement rates decline by more than 5 percent over the same period. Focusing on income, this study then compares the characteristics and income changes of retirees who are better and worse off.

For each measure of interest, most of the tables report the mean value between the $40^{\text {th }}$ and $60^{\text {th }}$ percentiles of the distribution. This statistic approximates the median, and better describes outcomes for typical people than the mean because it is less sensitive to extreme values. It is also a better statistic than the median, because the median value gives the breakdown for a single observation, which may not be representative of people in the center of the distribution. By using 20 percent of the sample, this statistic better describes the composition of wealth and income for typical cases. Unless otherwise noted, this statistic is referred to as the median throughout the paper.

The analytic sample includes noninstitutionalized adults who survive until at least age 80 . This study compares differences in economic resources by personal characteristics, including 
gender, marital status, race/ethnicity, education, health status, living arrangements, housing tenure, work status, labor force experience, and income level. It also measures the extent to which changes in marital status, health status, living arrangements, and work status affect retirement well-being at ages 67 and 80 . Results are reported at the individual level, separately for current retirees and boomers. Current retirees include those born between 1926 and 1939, and boomers include those born between 1945 and 1965. All wealth and income projections are expressed in 2005 dollars.

\section{RESULTS}

First the paper describes how the characteristics of retirees are expected to change as they age. Next it examines the level and composition of family resources, namely retirement wealth and income, by personal and economic characteristics. Then it assesses the adequacy of retirement income by analyzing replacement rates, poverty rates, and the share of retirees with income below 45 percent of the national average wage. It then considers the characteristics of retirees whose situations are projected to be better off or worse off at age 80 compared with their circumstances at age 67. Finally, it considers how changes in marital status, health, living arrangements, and work status relate to changes in retirement resources and the adequacy of these resources.

\section{Characteristics of Older Adults at Ages 67 and 80}

At baseline, age 67, the characteristics of retirees are projected to differ across birth cohorts in ways that are well documented (Butrica, Iams, and Smith 2003; Butrica and Uccello 2004). Boomer retirees are significantly less likely than current retirees to be non-Hispanic white and high-school dropouts, and significantly more likely to have college degrees and many years of work experience (table 1).

Thirteen years later, at age 80, both current and boomer retirees are significantly less likely to be married, in good health, or working (table 2). However, boomers are slightly less likely than current retirees to be married or working and slightly more likely to be healthy. Between 65-70 percent of retirees in both cohorts are projected to be married at age 67, but just

over 50 percent will be married at age 80 . Due to age, most of these marriages will likely end in 
widowhood. For most retirees, health also declines with age. MINT projects that between 70-73 percent of retirees in both cohorts will be healthy at age 67, but that only 56-60 percent will be healthy at age 80 . As retirees become widows and widowers, one might expect them to start living with adult children or friends. However, MINT projects that the proportion of retirees living alone will remain relatively constant between ages 67 and 80 . Finally, about half of retirees (or their spouses) are likely to be working at age 67. As expected, the share still working at age 80 is expected to decline substantially to only 7-11 percent.

\section{Changes in Family Resources as Retirees Age}

\section{Family Wealth}

As documented by Butrica and Uccello (2004), boomers are expected to start their retirement with considerably more wealth than current retirees (table 3). Between ages 67 and 80, family wealth is projected to decline by more than one-third for both cohorts of retireesfrom $\$ 672,000$ to $\$ 430,000$ for current retirees, and from $\$ 898,000$ to $\$ 591,000$ for boomers.

Declines are largest for the most economically vulnerable populations, namely nonHispanic blacks, high-school dropouts, renters, and those with the lowest incomes. For example, the family wealth of non-Hispanic blacks is projected to decline over time by 49 percent for current retirees and by 45 percent for boomer retirees. Additionally, those in the lowest income quintile are expected to experience a decline in wealth of 44 percent among current retirees and 41 percent among boomers. In contrast, the wealth of those in the highest income quintile is projected to decline over time by only 24 percent for current retirees and 21 percent for boomers. In general, boomer retirees are projected to experience smaller percentage declines in family wealth between ages 67 and 80 than current retirees.

The decline is wealth is driven in large part by the decline in Social Security and DB pension wealth, which are computed based on life expectancies at ages 67 or 80 (table 4). Average life expectancy is 17 years at age 67, but only 9 years at age 80 (Arias 2006). Since Social Security and DB benefits are paid out fewer years at age 80 than at age 67, Social Security and DB pension wealth are lower at age 80 than at age 67. For example, Social Security wealth of the typical current retiree is $\$ 315,000$ at age 67 , but only $\$ 159,000$ at age 80 . Similarly, DB pension wealth of the typical current retiree is $\$ 121,000$ at age 67 , but only $\$ 49,000$ at age 80 . Unlike Social Security wealth, DB pension wealth may decline as people age for a reason other 
than just shorter life expectancies. Private pension wealth can erode over time with inflation, because most plans do not peg benefits to changes in the cost of living.

Even excluding Social Security and DB pension wealth, family wealth is projected to decline between ages 67 and 80, though much less dramatically-between 6 and 8 percent for the typical retiree. Current retirees are projected to consume their wealth (excluding Social Security and DB pensions) at an average of $\$ 1,000$ per year between ages 67 and 80 . Boomer retirees, in contrast, are projected to spend their wealth nearly twice as fast-averaging \$1,900 per year. This decline in wealth largely reflects declines in financial wealth and retirement accounts, and may result for a number of reasons. For example, Johnson, Mermin, and Uccello (2006) found that median household-size-adjusted wealth declined over time for adults ages 70 and older who experienced the onset of a severe disability or whose spouses experienced a major medical condition.

\section{Family Income}

Given their projections of higher wealth at age 67, it is not surprising to find in table 5 that the typical boomer is also projected to have higher income at age $67(\$ 66,000)$ than the typical current retiree $(\$ 50,000)$. Family income is projected to decline between ages 67 and 80 by 8 percent for current retirees and 12 percent for boomers. Despite a larger percentage drop in income over time, however, boomers are expected to have higher incomes at age $80(\$ 58,000)$ than current retirees $(\$ 46,000)$.

Retirees who were married, co-residing, or working at age 67 are expected to experience the largest percentage decreases in family income between ages 67 and 80. Family income is projected to decline by 13-15 percent for female retirees, but by only 4-7 percent for male retirees. Also interesting is that family income is projected to increase slightly at older ages for low-income retirees in both cohorts. In general, boomer retirees are projected to experience larger percentage declines in family income between ages 67 and 80 than current retirees.

Except for earnings, the sources of retirement income are similar at ages 67 and 80 (table 6). As people age, they are less likely to work. As a result, 47 percent of current retirees have earnings at age 67 (their own or their spouses), but only 11 percent have earnings at age 80 . Boomer retirees are slightly more likely than current retirees to have earnings at age 67, and slightly less likely to have earnings at age 80. Between ages 67 and 80, family earnings decline 
by $\$ 6,000$ for current retirees and $\$ 11,000$ for boomer retirees. In fact, the drop in family income between ages 67 and 80 is driven largely by the decline in earnings as people leave the labor force.

Although financial wealth and retirement account balances are projected to decline as people age (table 4), the income generated from this wealth is projected to increase slightly. This is because the decline in wealth is not large enough to offset the impact of shorter life spans at age 80 than at age 67, which will increase annuity payments for similar wealth balances. For example, a current retiree with $\$ 110,000$ in financial wealth at age 67 could expect to receive an annuity of about $\$ 6,500$ per year ( $\$ 110,000 / 17$ ). For their annuity payment to be lower at age 80 , when their life expectancy is only 9 years, their financial wealth would have to be less than $\$ 59,000$ (\$6,500*9). In actuality, MINT projects that the typical current retiree will have $\$ 98,000$ in financial wealth—not $\$ 59,000$.

Earnings account for 14-18 percent of total family income for 67 year-old retirees. Due to the large number of workers exiting the labor force, earnings represent only 2 percent of family income for all 80 year-old retirees_-both current retirees and boomers. As retirees age, earnings decrease in importance, while Social Security increases in importance. At age 67, Social Security benefits represent about 34 percent of total family income for all retirees. At age 80, Social Security benefits account for 39-43 percent of total family income for current and boomer retirees.

Low-income retirees are likely to rely heavily on Social Security benefits to finance their retirement. Because Social Security benefits are inflation-protected, they do not decline over time. As a result, low-income retirees are more likely than other retirees to see their incomes remain constant or slightly increase as they age, unless they experience a life-changing event.

\section{How Does the Adequacy of Family Resources Change as Retirees Age?}

\section{Replacement Rates}

Replacement rates are the ratio of per capita income (excluding imputed rent and coresident income) at ages 67 or 80 to average shared earnings between ages 22 and 62 . As Butrica, Iams, and Smith (2003) and Butrica and Uccello (2004) have already documented, despite having higher retirement incomes, boomers are less likely than current retirees to be able to maintain their pre-retirement living standards. That is, boomers are projected to have lower 
replacement rates than current retirees. At age 67, the typical current retiree is projected to have enough retirement income to replace 105 percent of his pre-retirement earnings. In contrast, the typical boomer is projected to have enough retirement income to replace only 93 percent of his pre-retirement earnings.

Since the incomes of typical retirees are projected to decline as they age (table 5), it follows that their replacement rates are also projected to decline (table 7). ${ }^{3}$ Current retirees are expected to experience declines in replacement rates from 105 percent at age 67 to 90 percent at age 80. In contrast, boomer retirees are expected to experience declines in replacement rates from 93 percent at age 67 to 79 percent at age 80 . As a result, the share with replacement rates below 75 percent is expected to increase from 29 to 40 percent for current retirees and from 35 to 47 percent for boomer retirees (table 8).

\section{Poverty}

Except for high school dropouts and older adults with little work experience, boomers are projected to have slightly lower poverty rates than current retirees (table 9). However, MINT projects very little change in poverty between ages 67 and 80 . Overall poverty rates are projected to remain steady at 5 percent for current retirees and 3 percent for boomers. Current retirees who are single, renters, and in the lowest income quintile at age 67 will experience declines in poverty rates ranging from 3-6 percentage points. Boomers in the lowest income quintile at age 67 will experience about a 3-percentage point decrease in poverty rates. Older adults in both cohorts who are in shared living arrangements at age 67 are projected to have a 3percentage point increase in poverty rates between ages 67 and 80 .

The analysis also computes the projected share of retirees with incomes less than twice the federal poverty level (table 10). These are individuals who are at risk of not being able to meet their consumption needs. Doubling the consumption need threshold from one to two times the federal poverty level would quadruple the share of retirees who could not meet their consumption needs. MINT projects very little change between ages 67 and 80 overall; however, there is quite a bit of variation by subgroup. For example, the share of non-Hispanic blacks who are near poor is projected to increase from 39 percent at age 67 to 44 percent at age 80 among

\footnotetext{
${ }^{3}$ Only the numerator of the replacement rate, which is per capita family income, differs between ages 67 and 80 . The denominator, average lifetime shared earnings, is the same at either age.
} 
current retirees. Among boomers, the share of non-Hispanic blacks who are near poor is projected to increase from 23 to 28 percent. The projected outcomes of Hispanics are nearly identical. Near poverty rates are also expected to increase substantially for older adults who at age 67 are in shared living arrangements, working, or in the second and third income quintiles. In contrast, near poverty rates are expected to decline by 18 percentage points for current retirees and 10 percentage points for boomer retirees in the first income quintile.

Even though overall incomes are projected to decline substantially between ages 67 and 80 , overall poverty rates are projected to remain fairly constant, in large part, because poverty thresholds are not adjusted to reflect real-wage increases. For this reason, the analysis also examines the share of retirees with income less than 45 percent of the national average wage (table 11). Using this measure of retirement adequacy reveals two main findings. First, boomers are slightly more likely than current retirees to have income below 45 percent of the national average wage. Second, unlike poverty rates which remain fairly constant and even decrease as retirees grow older, the share of retirees with per capita income less than 45 percent of the national average wage is projected to increase by 7-8 percentage points between ages 67 and 80 for both current retirees and boomers. Demographic and economic subgroups who are likely to experience the largest increases in near poverty rates between ages 67 and 80 will also experience the largest increases in the share with per capita incomes below 45 percent of the national average wage.

These findings reflect that poverty thresholds increase with inflation, but wages increase faster than inflation. For instance, in 1993, \$8,740 was the poverty threshold for married couples ages 65 or older and \$10,410 was 45 percent of the national average wage. By 2020, the gap between these amounts is projected to increase considerably - the poverty threshold will increase to $\$ 17,035$, and 45 percent of the national average wage will increase to $\$ 29,322 .{ }^{4}$

\section{Who Is Better or Worse off at Age 67 than at Age 80?}

This section considers who is better or worse off at age 80 than at age 67 along a number of dimensions. Someone is better off if their wealth, income, or replacement rates at age 67 increase by more than 5 percent at age 80 . Likewise, they are worse off if these measures

\footnotetext{
${ }^{4}$ Based on the intermediate assumptions in Table V.B1 of the 2004 OASDI Trustees Report (Board of Trustees 2004).
} 
decrease by more than 5 percent between ages 67 and 80 . They are better off with regard to poverty, near poverty, 45 percent of the national average wage, 75 percent replacement rate, and 50 percent replacement rate if they were below these thresholds at age 67 and above these thresholds at age 80. Likewise, they are worse off if they were above these thresholds at age 67 and below these thresholds at age 80 .

Given the expected decline between ages 67 and 80 in Social Security wealth and DB pension wealth, it is somewhat surprising to find any retirees who experience a simultaneous increase in their overall wealth (table 12). But 4 percent of current retirees and 2 percent of boomers are projected to have family wealth at age 80 that is more than 5 percent higher than their family wealth at age 67. Although this result is not explored further, it may reflect retirees who married between ages 67 and 80 to a much wealthier partner. More than 90 percent of all retirees are projected to experience more than a 5 percent decline in family wealth between ages 67 and 80.

The findings with regard to family income are much different. Close to an equal percentage of all retirees are expected to have more than a 5 percent increase in income and more than a 5 percent decrease in income between ages 67 and 80.43 percent of current retirees are projected to have higher income at age 80 than at age 67, and 42 percent are projected to have lower income at age 80 than at age 67 . The results are very similar for boomer retirees.

The majority of retirees do not experience a large enough change in income between ages 67 and 80 to put them into or move them out of poverty — regardless of how poverty is measured. Among current retirees, 2 percent will be poor at age 67 but not at age 80 (better off). Another 2 percent will not be poor at age 67 but poor at age 80 (worse off). The movement in and out of poverty is greater using different definitions of poverty. Based on the near poverty rates of current retirees, 5 percent will be better off and 6 percent will be worse off later in retirement. This pattern is expected to be similar for boomer retirees, although boomers are less likely than current retirees to be better or worse off with regard to either poverty or near poverty. Using a relative measure of adequacy, 45 percent of the national average wage, the results are similar for current and boomer retirees. That is, 4 percent of retirees will be better off and about 12 percent of retirees will be worse off between ages 67 and 80 . 
The results are also similar for current retirees and boomers with regard to replacement rates. About 30 percent of all retirees are expected to be better off because their replacement rates will increase by more than 5 percent between ages 67 and 80 . However, replacement rates will increase to above 75 percent for only 5 percent of retirees and to above 50 percent for only 3 percent of retirees. About 57-59 percent of retirees are expected to be worse off because their replacement rates will decrease by more than 5 percent between ages 67 and 80 . Replacement rates will decrease to below 75 percent for about 16-17 percent of retirees and to below 50 percent for about 9-10 percent of retirees.

Focusing on retirees who are better or worse off with regard to income, the analysis considers their characteristics and median change in income between ages 67 and 80 . Table 13 looks at those whose incomes increased by more than 5 percent during this period. Compared with their overall sample, current retirees who are better off are significantly more likely to be male (42 versus 38 percent) and not working at age 67 (65 versus 53 percent). In all other ways documented, those who are better off are very similar to the overall sample. The median increase in income for current retirees who are better off is $\$ 14,000$; however, there is a lot of variation by subgroup. For example, the median increase in income is only $\$ 8,000$ for nonHispanic blacks compared with $\$ 15,000$ for non-Hispanic whites. Also, the median increase in income is $\$ 9,000$ for high-school dropouts compared with $\$ 23,000$ for college graduates. Finally, those in the lowest income quintile have a median increase in income of only $\$ 6,000$. In contrast, those in the highest income quintile have a median increase in income of $\$ 47,000$. In general, those who tend to be economically advantaged, such as non-Hispanic whites, college graduates, and high-income holders, are projected to have the largest increases in income.

Like current retirees, boomers who are better off are significantly more likely to be male (43 versus 38 percent) and not working at age 67 (69 versus 51 percent). They are also more likely to be single at age 67 (40 versus 35 percent). The median increase in income for boomer retirees is projected to be larger $(\$ 17,000)$ than that for current retirees $(\$ 14,000)$. Across all subgroups, the increase in income is larger among boomers than it is among current retirees. However, economically advantaged adults are expected to experience larger increases in income among boomers than among current retirees. For example, the median increase in income differs by $\$ 41,000$ for current retirees in the lowest income quintile versus those in the highest income quintile $(\$ 47,000-\$ 6,000)$. In contrast, the median increase in income differs by $\$ 68,000$ for 
boomer retirees in the lowest income quintile versus those in the highest income quintile $(\$ 73,000-\$ 5,000)$.

Table 14 considers those whose incomes decreased by more than 5 percent between ages 67 and 80. Compared with their overall sample, current retirees who are worse off are significantly more likely to be married (78 versus 70 percent) and working at age 67 (65 versus 47 percent), and significantly less likely to be in the lowest income quintile at age 67 (12 versus 20 percent). The median decrease in income for current retirees who are worse off is $\$ 16,000$. Perhaps because they tend to have more to lose, the most economically advantaged groups generally have the largest declines in income as they age. For example, the median decrease in income is only $\$ 11,000$ for high-school dropouts compared with $\$ 24,000$ for college graduates. And those in the lowest income quintile have a median decrease in income of only $\$ 4,000$ compared with $\$ 42,000$ among those in the highest income quintile. Although the magnitude of change is generally larger for boomers than for current retirees, many of the observed relationships are similar across cohorts.

\section{Factors Related to Changes in Family Resources as Retirees Age}

Economic status is highly correlated with changes in life events such as marriage, health, living arrangements, and work. For example, Johnson, Mermin, and Uccello (2006) find that job layoffs, divorce, and the onset of health related work limitations reduced household wealth by as much as 50 percent for some adults ages 51 to 61 . This section explores how life-changing events relate to changes in family resources and economic well-being during retirement.

\section{Marital Status}

This section begins by considering the relationship between marriage and economic wellbeing over time (table 15). Married adults who become widowed or divorced between ages 67 and 80 are projected to have the largest decline in wealth and income and the largest increase in poverty. This category describes 17 percent of current retirees. Median wealth is projected to decline by 44 percent from $\$ 673,000$ when married to only $\$ 380,000$ when single. Likewise, median income is projected to fall by 37 percent from $\$ 52,000$ to $\$ 33,000$. The percent poor will increase from 4 to 6 percent and the percent near poor will increase from 19 to 27 percent. Replacement rates increase even though income decreases because they are measured on a per 
capita basis. On a family basis, incomes are higher when married than when single; however, on a per capita basis, incomes are lower when married than when single. As a result, median replacement rates are projected to increase slightly from 101 to 105 percent. Note that the share with income below 45 percent of the national average wage is projected to remain at about 29 percent.

Although only 2 percent of current retirees are expected to marry between ages 67 and 80, they are projected to have the smallest decrease in wealth, largest increase in income, and largest decrease in poverty during retirement. Median wealth is projected to decline by 20 percent, while median income is projected to increase by 63 percent. The percent poor will decrease from 10 to 3 percent and the percent near poor will decline from 31 to 19 percent. Median replacement rates decline from 104 percent to 80 percent because median income actually declines on a per capita basis (from \$30,000 to \$24,500), which is the metric used in the replacement rates. For the same reason, the share with per capita income below 45 percent of the national average wage is projected to increase from 22 percent to 38 percent.

\section{Health Status}

The worsening of health normally associated with age can have severe consequences for economic well-being. Among healthy current retirees, nearly 30 percent are expected to suffer poor health by age 80 (table 16). Their median wealth is expected to decline by 38 percent from $\$ 601,000$ to $\$ 372,000$, and their median income is expected to decline by 13 percent (more than any other group) from $\$ 46,000$ to $\$ 40,000$. The share with income below 45 percent of the national average wage is projected to increase from 25 to 35 percent.

Among unhealthy current retirees, 15 percent are expected to improve their health by age 80. Their median wealth is expected to decline by 35 percent from $\$ 649,000$ to $\$ 419,000$, and their median income is expected to decline by only 6 percent from $\$ 49,000$ to $\$ 46,000$. The share with income below 45 percent of the national average wage is projected to increase from 25 to 32 percent. Only current retirees who remain healthy throughout the period have better outcomes. 


\section{Living Arrangements}

Unlike the measure of family wealth, the measure of family income captures the economic resources that co-residents contribute to the family unit. That is why family wealth declines between ages 67 and 80 regardless of living arrangements, while family income increases for those who begin cohabiting at age 80 (table 17). Only 5 percent of current retirees are expected to fall into this category. They have the lowest income of retirees in any other living arrangement at age 67 (\$42,000), and the highest income of all other retirees at age 80 $(\$ 76,000)$. As a result, the 7 percent poverty rate at age 67 is projected to be completely eliminated at age 80 . Near poverty rates are expected to decline from 25 to 7 percent, and the share with income less than 45 percent of the national average wage is expected to fall from 27 to 4 percent. Replacement rates decline from 106 percent to 89 percent because median income actually declines on a per capita basis (from $\$ 42,000$ to $\$ 38,000$ ).

About 7 percent of current retirees will begin living alone at age 80 . They have the highest income of retirees in any other living arrangement at age $67(\$ 64,000)$, and the lowest income of all other retirees at age $80(\$ 31,000)$. As a result, poverty rates are projected to nearly quadruple from 3 to 11 percent, and near poverty rates will more than double from 14 to 36 percent. The share with income less than 45 percent of the national average wage is expected to increase from 9 to 45 percent, while replacement rates are expected to decline from 103 percent to 87 percent.

\section{Work Status}

Older adults who switch between working and not working are projected to experience the largest change in their retirement resources (table 18). Nearly two-fifths of current retirees are projected to retire (or have a spouse who retires) between ages 67 and 80. Their median income is projected to decline by 24 percent from $\$ 63,000$ to $\$ 48,000$. Poverty and near poverty rates are projected to double and the share with income below 45 percent of the national average wage is projected to increase from 11 to 28 percent. Median replacement rates are projected to decline from 120 to 81 percent. Consequently, the share whose replacement rates fall below 75 percent is expected to increase from 19 to 45 percent. Likewise, the share whose replacement rates fall below 50 percent is expected to increase from 5 to 19 percent. 
Only 3 percent of current retirees are expected to begin working between ages 67 and 80 . Their median income is projected to increase by 58 percent from $\$ 48,000$ to $\$ 76,000$. The poverty rate, near poverty rate, and share with income below 45 percent of the national average wage is projected to decline by close to half. Median replacement rates are projected to increase from 88 to 135 percent. Consequently, the share whose replacement rates fall below 75 percent is expected to decrease from 35 to 16 percent. Likewise, the share whose replacement rates fall below 50 percent is expected to decrease from 14 to 4 percent.

\section{CONCLUSIONS}

Typical older adults experience a decline in retirement wealth and income between ages 67 and 80. More than two-fifths of retirees will have significantly less income at age 80 than they did at age 67, with the median decline in income being $\$ 16,000$ for current retirees and $\$ 23,000$ for boomers. Some older adults, however, will be better off later in retirement. Approximately two-fifths of retirees will have significantly more income at age 80 than they did at age 67 , with the median increase in income being $\$ 14,000$ for current retirees and $\$ 17,000$ for boomers.

At least some of the change in economic well-being during retirement is related to changes in marital status, health status, living arrangements, and work status. Older adults who are married or working at 67 are most likely to experience declines in income between ages 67 and 80 because they have a high probability of becoming widowed or retiring from the labor force. For example, one-fifth of retirees in the analysis become widowed or divorced between ages 67 and 80 and experience a corresponding decline in median income of 35-37 percent. Also, two-fifths of older adults quit working between ages 67 and 80 and face a 24-25 percent decline in their median income. On the flip side, economic well-being increases for those who marry or begin working between ages 67 and 80 . However, these events are significantly less common.

As shown in previous studies, boomer retirees are projected to have higher wealth and income than current retirees at both ages 67 and 80 . Although the magnitude of change in resources between ages 67 and 80 is generally larger for boomers than for current retirees, many of the observed relationships are similar across cohorts. 
As policymakers debate Social Security, health insurance, and long-term care insurance, it is important to recognize the factors associated with changes in economic security during retirement and their potential impact on retirees' economic well-being. The study findings may even be somewhat optimistic because of the uncertainty of promised Social Security benefits and rising health care and long-term care costs.

While encouraging workers to begin saving for retirement when they are young is imperative, it is only the first step. When Social Security benefits first became payable in 1940, the average worker retired at 68. To retire for an equivalent number of years in 2005 would mean retiring at 74; however, workers today retire on average at around age 63 (Steuerle 2005). For this reason, it is no longer enough to be financially prepared for the first year of retirement. Future retirees will need to consider whether their financial resources are sufficient to support themselves throughout retirement. They need to plan their retirement finances believing that they will live a very long time, they will outlive their spouses, and they will experience major health problems. Only then might they be able to enjoy the golden years. 


\section{REFERENCES}

Arias, Elizabeth. 2006. “United States Life Tables, 2003”. National Vital Statistics Reports. 54(14): 1-40.

Board of Trustees of the Federal Old-Age and Survivors Insurance and Disability Insurance Trust Funds. 2004. Annual Report. Washington, DC: U.S. Government Printing Office.

Butrica, Barbara A., and Cori E. Uccello. 2004. “How Will Boomers Fare at Retirement?” Final Report to the AARP Public Policy Institute. Washington, DC: AARP.

Butrica, Barbara A., Howard M. Iams, and Karen E. Smith. 2003. "It’s All Relative: Understanding the Retirement Prospects of Baby Boomers.” Center for Retirement Research Working Paper No. 2003-21. Chestnut Hill, MA: Center for Retirement Research at Boston College.

Coile, Courtney, and Kevin Milligan. 2006. "What Happens to Household Portfolios After Retirement?” Issue in Brief No. 56. Chestnut Hill, MA: Center for Retirement Research at Boston College. Available at http://www.bc.edu/centers/crr/ib_56.shtml.

Gustman, Alan L., and Thomas L. Steinmeier. 1999. "Effects of Pensions on Savings: Analysis with Data from the Health and Retirement Study.” Carnegie-Rochester Conference Series 50(July): 271-326.

Haveman, Robert, Karen Holden, Barbara Wolfe, and Andrei Romanov. 2004. "Do Retired Workers in the U.S. Have Sufficient Savings?: An Assessment at the Time of Retirement and Ten Years Later.” Available at http://gemini.econ.umd.edu/cgibin/conference/download.cgi?db_name=IIPF60\&paper_id=29.

Haveman, Robert, Karen Holden, Barbara Wolfe, and Shane Sherlund. 2003. "Have Newly Retired Workers in the U.S. Saved Enough to Maintain Well-Being through Retirement Years?” Paper presented at 2003 Annual APPAM Research Conference, Washington, D.C.

Johnson, Richard W., Gordon B. T. Mermin, and Cori E. Uccello. 2006. "How Secure Are Retirement Nest Eggs?” Issue in Brief No. 45. Chestnut Hill, MA: Center for Retirement Research at Boston College. Available at http://www.bc.edu/centers/crr/ib_45.shtml.

Moore, James F., and Olivia S. Mitchell. 2000. "Projected Retirement Wealth and Savings Adequacy in the Health and Retirement Study.” In Olivia S. Mitchell, P. Brett Hammond, and Anna M. Rappaport, eds., Forecasting Retirement Needs and Retirement Wealth (pp. 68-94). Philadelphia, PA: Pension Research Council and the University of Pennsylvania Press. 
Smith, Karen E., David B. Cashin, and Melissa M. Favreault. 2005. "Modeling Income in the Near Term 4.” Final Report, SSA Contract No: 600-01-60123. Washington, DC: The Urban Institute.

Smith, Karen E. 2002. "How Will Recent Patterns of Earnings Inequality Affect Future Retirement Incomes?” Final Report for AARP. Washington, DC: The Urban Institute.

Steuerle, C. Eugene. 2005. “Alternatives to Strengthen Social Security.” Testimony before the U.S. Committee on Ways and Means of the U.S. House of Representatives, May 12. 
Table 1. Characteristics of Older Adults at Age 67

\begin{tabular}{|c|c|c|}
\hline & \multicolumn{2}{|c|}{ Age 67} \\
\hline & $\begin{array}{c}\text { Current } \\
\text { Retirees } \\
\end{array}$ & Boomers \\
\hline All & $100 \%$ & $100 \%$ \\
\hline $\begin{array}{l}\text { Gender } \\
\text { Female } \\
\text { Male }\end{array}$ & $\begin{array}{l}62 \\
38\end{array}$ & $\begin{array}{l}62 \\
38\end{array}$ \\
\hline $\begin{array}{l}\text { Marital Status } \\
\text { Married } \\
\text { Single }\end{array}$ & $\begin{array}{l}70 \\
30\end{array}$ & $\begin{array}{l}65 \\
35\end{array}$ \\
\hline $\begin{array}{l}\text { Race/Ethnicity } \\
\text { Non-Hispanic white } \\
\text { Non-Hispanic black } \\
\text { Hispanic } \\
\text { Asian \& Native American }\end{array}$ & $\begin{array}{c}83 \\
8 \\
6 \\
3\end{array}$ & $\begin{array}{l}76 \\
9 \\
9 \\
6\end{array}$ \\
\hline $\begin{array}{l}\text { Education } \\
\text { High school dropout } \\
\text { High school graduate } \\
\text { College graduate }\end{array}$ & $\begin{array}{l}21 \\
59 \\
20\end{array}$ & $\begin{array}{c}9 \\
60 \\
31\end{array}$ \\
\hline $\begin{array}{l}\text { Health Status } \\
\text { Healthy } \\
\text { Unhealthy }\end{array}$ & $\begin{array}{l}70 \\
30\end{array}$ & $\begin{array}{l}73 \\
27\end{array}$ \\
\hline $\begin{array}{l}\text { Living Arrangements } \\
\text { Alone } \\
\text { Shared }\end{array}$ & $\begin{array}{l}84 \\
16\end{array}$ & $\begin{array}{l}86 \\
14\end{array}$ \\
\hline $\begin{array}{l}\text { Housing Tenure } \\
\text { Rent } \\
\text { Own }\end{array}$ & $\begin{array}{l}18 \\
82\end{array}$ & $\begin{array}{l}13 \\
87\end{array}$ \\
\hline $\begin{array}{l}\text { Work Status } \\
\text { Not Working } \\
\text { Working }\end{array}$ & $\begin{array}{l}53 \\
47\end{array}$ & $\begin{array}{l}51 \\
50\end{array}$ \\
\hline $\begin{array}{l}\text { Labor Force Experience } \\
\text { Less than } 20 \text { years } \\
20 \text { to } 29 \text { years } \\
30 \text { or more year }\end{array}$ & $\begin{array}{l}30 \\
21 \\
49\end{array}$ & $\begin{array}{l}14 \\
14 \\
72\end{array}$ \\
\hline
\end{tabular}

Notes: Current retirees are born between 1926-39. Boomers are born between 1946-65.

Source: Authors' tabulations of MINT (see text for details). 
Table 2. Characteristics of Older Adults at Ages 67 and 80

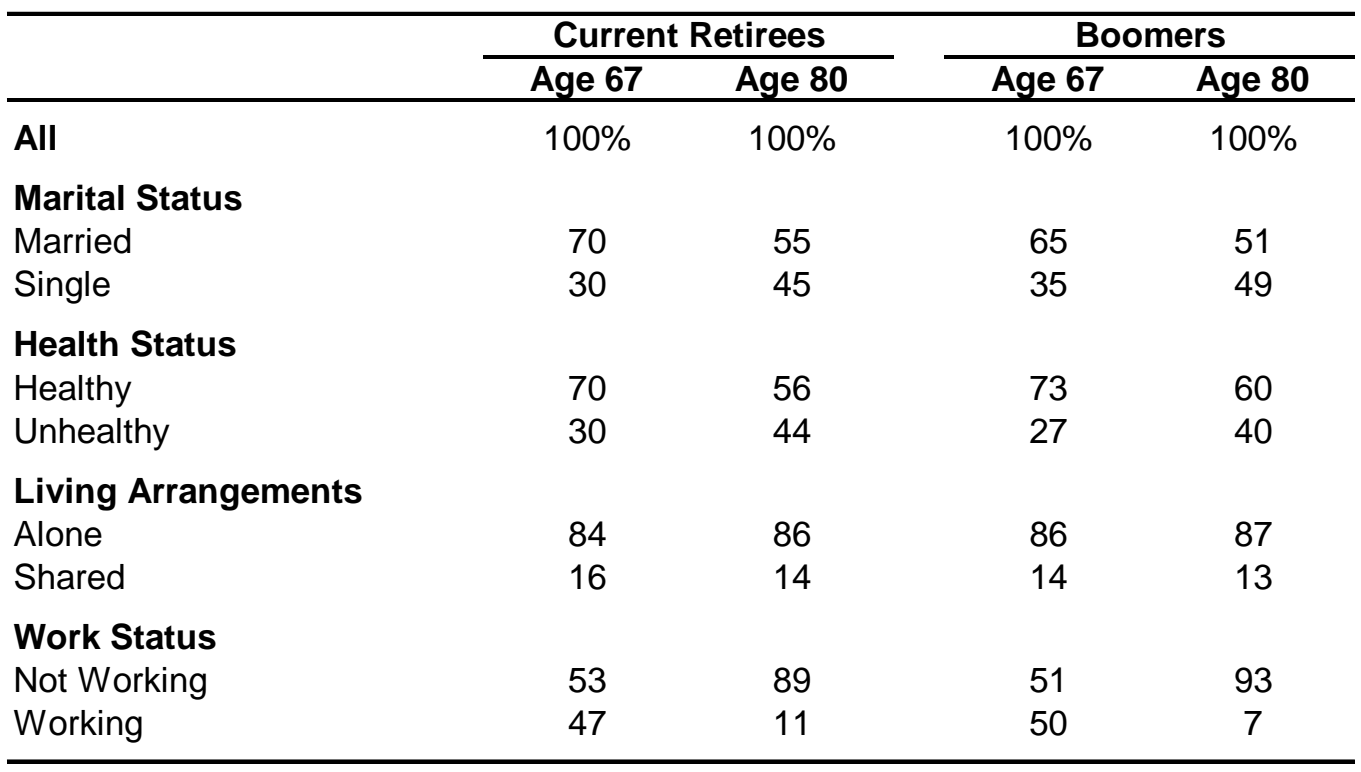

Notes: Current retirees are born between 1926-39. Boomers are born between 1946-65.

Source: Authors' tabulations of MINT (see text for details). 
Table 3. Median Family Wealth of Older Adults at Ages 67 and 80 (in thousands, \$2005)

\begin{tabular}{|c|c|c|c|c|}
\hline \multirow[b]{2}{*}{ Age 67 Status } & \multicolumn{2}{|c|}{ Current Retirees } & \multicolumn{2}{|c|}{ Boomers } \\
\hline & Age 67 & Age 80 & Age 67 & Age 80 \\
\hline All & $\$ 672$ & $\$ 430$ & $\$ 898$ & $\$ 591$ \\
\hline \multicolumn{5}{|l|}{ Gender } \\
\hline Female & 625 & 411 & 852 & 570 \\
\hline Male & 745 & 465 & 976 & 629 \\
\hline \multicolumn{5}{|l|}{ Marital Status } \\
\hline Married & 815 & 517 & 1,109 & 717 \\
\hline Single & 416 & 277 & 602 & 426 \\
\hline \multicolumn{5}{|l|}{ Race/Ethnicity } \\
\hline Non-Hispanic white & 741 & 486 & 1,026 & 698 \\
\hline Non-Hispanic black & 360 & 184 & 542 & 300 \\
\hline Hispanic & 351 & 193 & 536 & 316 \\
\hline Asian \& Native American & 426 & 266 & 670 & 452 \\
\hline \multicolumn{5}{|l|}{ Education } \\
\hline High school dropout & 366 & 202 & 359 & 192 \\
\hline High school graduate & 684 & 441 & 782 & 500 \\
\hline College graduate & 1,143 & 808 & 1,565 & 1,137 \\
\hline \multicolumn{5}{|l|}{ Health Status } \\
\hline Healthy & 727 & 473 & 971 & 649 \\
\hline Unhealthy & 552 & 337 & 714 & 453 \\
\hline \multicolumn{5}{|l|}{ Living Arrangements } \\
\hline Alone & 710 & 459 & 945 & 625 \\
\hline Shared & 483 & 296 & 631 & 407 \\
\hline \multicolumn{5}{|l|}{ Housing Tenure } \\
\hline Rent & 280 & 146 & 338 & 209 \\
\hline Own & 767 & 499 & 1,009 & 667 \\
\hline \multicolumn{5}{|l|}{ Work Status } \\
\hline Not Working & 587 & 415 & 772 & 582 \\
\hline Working & 770 & 553 & 1,019 & 717 \\
\hline \multicolumn{5}{|l|}{ Labor Force Experience } \\
\hline Less than 20 years & 524 & 340 & 383 & 242 \\
\hline 20 to 29 years & 651 & 430 & 699 & 456 \\
\hline 30 or more year & 758 & 483 & 1,032 & 690 \\
\hline \multicolumn{5}{|l|}{ Income Quintile } \\
\hline 1st Quintile & 254 & 143 & 343 & 202 \\
\hline 2nd Quintile & 501 & 308 & 675 & 421 \\
\hline 3rd Quintile & 730 & 459 & 962 & 607 \\
\hline 4th Quintile & 990 & 644 & 1,361 & 916 \\
\hline 5th Quintile & 1,748 & 1,320 & 3,012 & 2,373 \\
\hline
\end{tabular}

Notes: Current retirees are born between 1926-39. Boomers are born between 1946-65. Marital status, health status, living arrangements, housing tenure, work status, and income quintile are as of age 67 . The median value is measured as the mean value between the 40th and 60th percentiles of the distribution.

Source: Authors' tabulations of MINT (see text for details). 
Table 4. Family Wealth of Older Adults at Ages 67 and 80

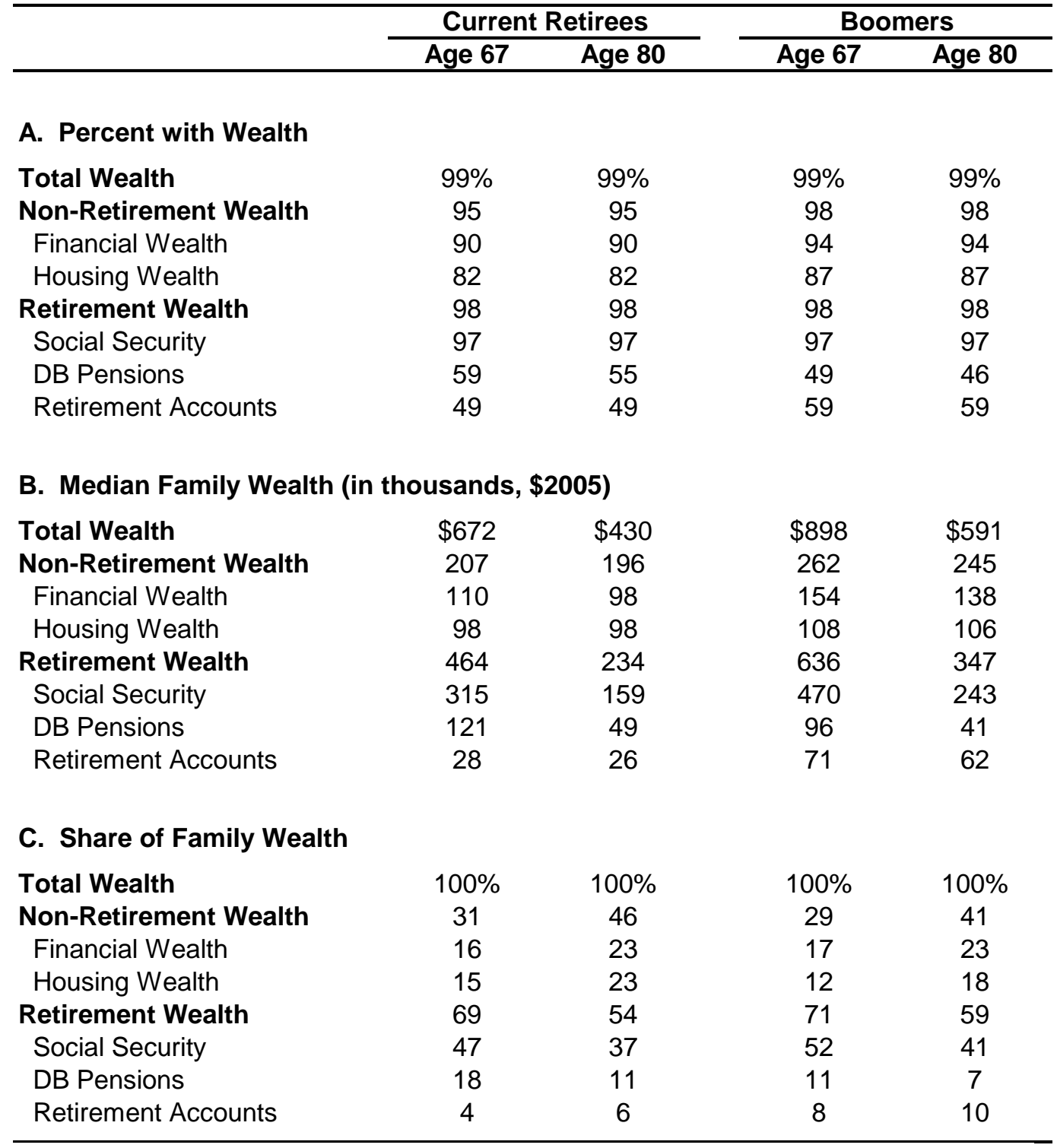

Notes: Current retirees are born between 1926-39. Boomers are born between 1946-65. The median value is measured as the mean value between the 40th and 60th percentiles of the distribution.

Source: Authors' tabulations of MINT (see text for details). 
Table 5. Median Family Income of Older Adults at Ages 67 and 80 (in thousands, \$2005)

\begin{tabular}{|c|c|c|c|c|}
\hline \multirow[b]{2}{*}{ Age 67 Status } & \multicolumn{2}{|c|}{ Current Retirees } & \multicolumn{2}{|c|}{ Boomers } \\
\hline & Age 67 & Age 80 & Age 67 & Age 80 \\
\hline All & $\$ 50$ & $\$ 46$ & $\$ 66$ & $\$ 58$ \\
\hline \multicolumn{5}{|l|}{ Gender } \\
\hline Female & 46 & 40 & 60 & 51 \\
\hline Male & 57 & 55 & 75 & 70 \\
\hline \multicolumn{5}{|l|}{ Marital Status } \\
\hline Married & 59 & 54 & 80 & 69 \\
\hline Single & 30 & 29 & 41 & 39 \\
\hline \multicolumn{5}{|l|}{ Race/Ethnicity } \\
\hline Non-Hispanic white & 53 & 50 & 71 & 64 \\
\hline Non-Hispanic black & 31 & 25 & 42 & 35 \\
\hline Hispanic & 35 & 29 & 50 & 40 \\
\hline Asian \& Native American & 47 & 41 & 70 & 63 \\
\hline \multicolumn{5}{|l|}{ Education } \\
\hline High school dropout & 31 & 28 & 33 & 29 \\
\hline High school graduate & 50 & 45 & 58 & 50 \\
\hline College graduate & 79 & 75 & 106 & 95 \\
\hline \multicolumn{5}{|l|}{ Health Status } \\
\hline Healthy & 54 & 50 & 70 & 62 \\
\hline Unhealthy & 43 & 39 & 55 & 48 \\
\hline \multicolumn{5}{|l|}{ Living Arrangements } \\
\hline Alone & 47 & 45 & 62 & 56 \\
\hline Shared & 63 & 56 & 85 & 70 \\
\hline \multicolumn{5}{|l|}{ Housing Tenure } \\
\hline Rent & 26 & 23 & 29 & 28 \\
\hline Own & 56 & 52 & 72 & 64 \\
\hline \multicolumn{5}{|l|}{ Work Status } \\
\hline Not Working & 38 & 39 & 46 & 49 \\
\hline Working & 64 & 53 & 85 & 67 \\
\hline \multicolumn{5}{|l|}{ Labor Force Experience } \\
\hline Less than 20 years & 40 & 35 & 37 & 32 \\
\hline 20 to 29 years & 49 & 44 & 53 & 45 \\
\hline 30 or more year & 56 & 52 & 73 & 65 \\
\hline \multicolumn{5}{|l|}{ Income Quintile } \\
\hline 1st Quintile & 16 & 17 & 19 & 21 \\
\hline 2nd Quintile & 32 & 31 & 41 & 39 \\
\hline 3rd Quintile & 50 & 49 & 65 & 59 \\
\hline 4th Quintile & 72 & 68 & 100 & 89 \\
\hline 5th Quintile & 125 & 123 & 198 & 194 \\
\hline
\end{tabular}

Notes: Current retirees are born between 1926-39. Boomers are born between 1946-65. Marital status, health status, living arrangements, housing tenure, work status, and income quintile are as of age 67 . The median value is measured as the mean value between the 40th and 60th percentiles of the distribution.

Source: Authors' tabulations of MINT (see text for details). 
Table 6. Family Income of Older Adults at Ages $\mathbf{6 7}$ and 80

\begin{tabular}{lcccccc}
\hline & \multicolumn{2}{c}{ Current Retirees } & & \multicolumn{2}{c}{ Boomers } \\
\cline { 2 - 3 } \cline { 5 - 6 } & Age 67 & Age 80 & & Age 67 & Age 80 \\
\hline & & & & & \\
A. Percent with Income & & & & & \\
Total Income & $100 \%$ & $100 \%$ & & $100 \%$ & $100 \%$ \\
Non-Retirement Income & 98 & 97 & & 99 & 99 \\
Financial Income & 90 & 90 & & 94 & 94 \\
Earnings & 47 & 11 & & 50 & 7 \\
SSI Benefits & 4 & 4 & & 2 & 2 \\
Imputed Rental Income & 82 & 82 & & 87 & 87 \\
Co-resident Income & 16 & 14 & & 13 & 12 \\
Retirement Income & 96 & 98 & & 97 & 98 \\
Social Security Benefits & 92 & 97 & & 94 & 97 \\
DB Pension Benefits & 54 & 56 & & 43 & 48 \\
Retirement Accounts & 49 & 49 & & 59 & 59
\end{tabular}

B. Median Family Income (in thousands,\$2005)

\begin{tabular}{lcccc} 
Total Income & $\$ 50$ & $\$ 46$ & $\$ 66$ & $\$ 58$ \\
Non-Retirement Income & 22 & 17 & 32 & 21 \\
Financial Income & 8 & 11 & 10 & 13 \\
Earnings & 7 & 1 & 12 & 1 \\
SSI Benefits & 0 & 0 & 0 & 0 \\
Imputed Rental Income & 3 & 3 & 4 & 4 \\
Co-resident Income & 4 & 2 & 6 & 4 \\
Retirement Income & 28 & 29 & 34 & 37 \\
Social Security Benefits & 17 & 18 & 23 & 25 \\
DB Pension Benefits & 9 & 8 & 6 & 6 \\
Retirement Accounts & 2 & 3 & 5 & 6 \\
& & & & \\
C. Share of Family Income & & & & \\
Total Income & $100 \%$ & $100 \%$ & $100 \%$ & $100 \%$ \\
Non-Retirement Income & 44 & 37 & 48 & 36 \\
Financial Income & 16 & 24 & 15 & 22 \\
Earnings & 14 & 2 & 18 & 2 \\
SSI Benefits & 0 & 0 & 0 & 0 \\
Imputed Rental Income & 6 & 7 & 6 & 7 \\
Co-resident Income & 8 & 4 & 9 & 7 \\
Retirement Income & 56 & 63 & 52 & 64 \\
Social Security Benefits & 34 & 39 & 35 & 43 \\
DB Pension Benefits & 18 & 17 & 9 & 10 \\
Retirement Accounts & 4 & 7 & 8 & 10 \\
\hline
\end{tabular}

Notes: Current retirees are born between 1926-39. Boomers are born between 1946-65. The median value is measured as the mean value between the 40th and 60th percentiles of the distribution.

Source: Authors' tabulations of MINT (see text for details). 
Table 7. Median Replacement Rates of Older Adults at Ages 67 and 80

\begin{tabular}{|c|c|c|c|c|}
\hline \multirow[b]{2}{*}{ Age 67 Status } & \multicolumn{2}{|c|}{ Current Retirees } & \multicolumn{2}{|c|}{ Boomers } \\
\hline & Age 67 & Age 80 & Age 67 & Age 80 \\
\hline All & $105 \%$ & $90 \%$ & $93 \%$ & $79 \%$ \\
\hline \multicolumn{5}{|l|}{ Gender } \\
\hline Female & 106 & 92 & 92 & 79 \\
\hline Male & 103 & 86 & 95 & 78 \\
\hline \multicolumn{5}{|l|}{ Marital Status } \\
\hline Married & 104 & 91 & 93 & 79 \\
\hline Single & 106 & 86 & 95 & 78 \\
\hline \multicolumn{5}{|l|}{ Race/Ethnicity } \\
\hline Non-Hispanic white & 105 & 90 & 93 & 79 \\
\hline Non-Hispanic black & 100 & 79 & 83 & 68 \\
\hline Hispanic & 102 & 81 & 91 & 74 \\
\hline Asian \& Native American & 148 & 122 & 123 & 105 \\
\hline \multicolumn{5}{|l|}{ Education } \\
\hline High school dropout & 95 & 81 & 97 & 84 \\
\hline High school graduate & 102 & 87 & 89 & 75 \\
\hline College graduate & 129 & 110 & 103 & 86 \\
\hline \multicolumn{5}{|l|}{ Health Status } \\
\hline Healthy & 106 & 91 & 93 & 79 \\
\hline Unhealthy & 102 & 86 & 93 & 79 \\
\hline \multicolumn{5}{|l|}{ Living Arrangements } \\
\hline Alone & 105 & 90 & 93 & 79 \\
\hline Shared & 104 & 86 & 94 & 78 \\
\hline \multicolumn{5}{|l|}{ Housing Tenure } \\
\hline Rent & 101 & 88 & 113 & 105 \\
\hline Own & 106 & 90 & 91 & 76 \\
\hline \multicolumn{5}{|l|}{ Work Status } \\
\hline Not Working & 91 & 86 & 78 & 76 \\
\hline Working & 120 & 125 & 110 & 119 \\
\hline \multicolumn{5}{|l|}{ Labor Force Experience } \\
\hline Less than 20 years & 127 & 117 & 135 & 129 \\
\hline 20 to 29 years & 112 & 94 & 100 & 85 \\
\hline 30 or more year & 94 & 77 & 88 & 72 \\
\hline \multicolumn{5}{|l|}{ Income Quintile } \\
\hline 1st Quintile & 72 & 71 & 69 & 69 \\
\hline 2nd Quintile & 81 & 71 & 73 & 65 \\
\hline 3rd Quintile & 92 & 82 & 85 & 70 \\
\hline 4th Quintile & 115 & 95 & 103 & 82 \\
\hline 5th Quintile & 186 & 157 & 160 & 137 \\
\hline
\end{tabular}

Notes: Current retirees are born between 1926-39. Boomers are born between 1946-65. Marital status, health status, living arrangements, housing tenure, work status, and income quintile are as of age 67. Replacement rates are calculated as the ratio of per capita income (excluding imputed rent and co-resident income) at ages 67 or 80 to shared lifetime earnings. Shared lifetime earnings is the average of wageindexed shared earnings between ages 22 and 62, where shared earnings are computed by assigning each individual half the total earnings of the couple in the years when the individual is married and his or her own earnings in years when not married. The median value is measured as the mean value between the 40th and 60th percentiles of the distribution.

Source: Authors' tabulations of MINT (see text for details). 
Table 8. Distribution of Replacement Rates

of Older Adults at Ages 67 and 80

\begin{tabular}{lccccc}
\hline Replacement & \multicolumn{2}{c}{ Current Retirees } & & \multicolumn{2}{c}{ Boomers } \\
\cline { 2 - 3 } \cline { 5 - 6 } Rate & Age 67 & Age 80 & & Age 67 & Age 80 \\
\hline$<\mathbf{2 5 \%}$ & $2 \%$ & $1 \%$ & & $2 \%$ & $1 \%$ \\
$<\mathbf{5 0} \%$ & $10 \%$ & $16 \%$ & & $13 \%$ & $19 \%$ \\
$<\mathbf{7 5 \%}$ & $29 \%$ & $40 \%$ & & $35 \%$ & $47 \%$ \\
$<\mathbf{1 0 0} \%$ & $47 \%$ & $57 \%$ & & $55 \%$ & $65 \%$ \\
$<\mathbf{2 0 0 \%}$ & $82 \%$ & $84 \%$ & & $85 \%$ & $87 \%$ \\
\hline
\end{tabular}

Notes: Current retirees are born between 1926-39. Boomers are born between 1946-65.

Replacement rates are calculated as the ratio of per capita income (excluding imputed rent and coresident income) at ages 67 or 80 to shared lifetime earnings. Shared lifetime earnings is the average of wage-indexed shared earnings between ages 22 and 62, where shared earnings are computed by assigning each individual half the total earnings of the couple in the years when the individual is married and his or her own earnings in years when not married.

Source: Authors' tabulations of MINT (see text for details). 
Table 9. Poverty Rates of Older Adults at Ages 67 and 80

\begin{tabular}{|c|c|c|c|c|}
\hline \multirow[b]{2}{*}{ Age 67 Status } & \multicolumn{2}{|c|}{ Current Retirees } & \multicolumn{2}{|c|}{ Boomers } \\
\hline & Age 67 & Age 80 & Age 67 & Age 80 \\
\hline All & $5 \%$ & $5 \%$ & $3 \%$ & $3 \%$ \\
\hline \multicolumn{5}{|l|}{ Gender } \\
\hline Female & 7 & 6 & 4 & 4 \\
\hline Male & 4 & 3 & 2 & 2 \\
\hline \multicolumn{5}{|l|}{ Marital Status } \\
\hline Married & 3 & 3 & 2 & 2 \\
\hline Single & 11 & 8 & 6 & 5 \\
\hline \multicolumn{5}{|l|}{ Race/Ethnicity } \\
\hline Non-Hispanic white & 4 & 3 & 2 & 2 \\
\hline Non-Hispanic black & 13 & 13 & 7 & 7 \\
\hline Hispanic & 13 & 12 & 6 & 5 \\
\hline Asian \& Native American & 14 & 13 & 8 & 8 \\
\hline \multicolumn{5}{|l|}{ Education } \\
\hline High school dropout & 13 & 12 & 15 & 13 \\
\hline High school graduate & 4 & 4 & 3 & 3 \\
\hline College graduate & 2 & 2 & 1 & 2 \\
\hline \multicolumn{5}{|l|}{ Health Status } \\
\hline Healthy & 4 & 4 & 3 & 3 \\
\hline Unhealthy & 8 & 7 & 5 & 4 \\
\hline \multicolumn{5}{|l|}{ Living Arrangements } \\
\hline Alone & 6 & 5 & 4 & 3 \\
\hline Shared & 2 & 5 & 0 & 3 \\
\hline \multicolumn{5}{|l|}{ Housing Tenure } \\
\hline Rent & 17 & 14 & 15 & 15 \\
\hline Own & 3 & 3 & 2 & 2 \\
\hline \multicolumn{5}{|l|}{ Work Status } \\
\hline Not Working & 9 & 8 & 7 & 5 \\
\hline Working & 1 & 2 & 0 & 1 \\
\hline \multicolumn{5}{|l|}{ Labor Force Experience } \\
\hline Less than 20 years & 12 & 11 & 18 & 17 \\
\hline 20 to 29 years & 6 & 4 & 4 & 4 \\
\hline 30 or more year & 1 & 1 & 1 & 1 \\
\hline \multicolumn{5}{|l|}{ Income Quintile } \\
\hline 1st Quintile & 27 & 21 & 17 & 14 \\
\hline 2nd Quintile & 1 & 2 & 0 & 1 \\
\hline 3rd Quintile & 0 & 1 & 0 & 1 \\
\hline 4th Quintile & 0 & 1 & 0 & 1 \\
\hline 5th Quintile & 0 & 0 & 0 & 0 \\
\hline
\end{tabular}

Notes: Current retirees are born between 1926-39. Boomers are born between 1946-65. Marital status, health status, living arrangements, housing tenure, work status, and income quintile are as of age 67.

Source: Authors' tabulations of MINT (see text for details). 
Table 10. Near Poverty Rates of Older Adults at Ages 67 and 80

\begin{tabular}{|c|c|c|c|c|}
\hline \multirow[b]{2}{*}{ Age 67 Status } & \multicolumn{2}{|c|}{ Current Retirees } & \multicolumn{2}{|c|}{ Boomers } \\
\hline & Age 67 & Age 80 & Age 67 & Age 80 \\
\hline All & $20 \%$ & $21 \%$ & $13 \%$ & $14 \%$ \\
\hline \multicolumn{5}{|l|}{ Gender } \\
\hline Female & 23 & 26 & 15 & 16 \\
\hline Male & 14 & 14 & 9 & 9 \\
\hline \multicolumn{5}{|l|}{ Marital Status } \\
\hline Married & 13 & 15 & 8 & 10 \\
\hline Single & 36 & 35 & 22 & 22 \\
\hline \multicolumn{5}{|l|}{ Race/Ethnicity } \\
\hline Non-Hispanic white & 16 & 17 & 10 & 10 \\
\hline Non-Hispanic black & 39 & 44 & 23 & 28 \\
\hline Hispanic & 38 & 44 & 21 & 25 \\
\hline Asian \& Native American & 33 & 37 & 20 & 22 \\
\hline \multicolumn{5}{|l|}{ Education } \\
\hline High school dropout & 40 & 42 & 38 & 41 \\
\hline High school graduate & 17 & 19 & 13 & 14 \\
\hline College graduate & 8 & 8 & 4 & 6 \\
\hline \multicolumn{5}{|l|}{ Health Status } \\
\hline Healthy & 17 & 18 & 11 & 12 \\
\hline Unhealthy & 26 & 28 & 18 & 19 \\
\hline \multicolumn{5}{|l|}{ Living Arrangements } \\
\hline Alone & 21 & 21 & 14 & 14 \\
\hline Shared & 15 & 21 & 6 & 14 \\
\hline \multicolumn{5}{|l|}{ Housing Tenure } \\
\hline Rent & 45 & 47 & 37 & 36 \\
\hline Own & 14 & 16 & 9 & 10 \\
\hline \multicolumn{5}{|l|}{ Work Status } \\
\hline Not Working & 31 & 28 & 22 & 19 \\
\hline Working & 7 & 14 & 3 & 8 \\
\hline \multicolumn{5}{|l|}{ Labor Force Experience } \\
\hline Less than 20 years & 33 & 35 & 39 & 40 \\
\hline 20 to 29 years & 21 & 23 & 19 & 21 \\
\hline 30 or more year & 11 & 13 & 6 & 7 \\
\hline \multicolumn{5}{|l|}{ Income Quintile } \\
\hline 1st Quintile & 90 & 72 & 61 & 51 \\
\hline 2nd Quintile & 8 & 23 & 2 & 10 \\
\hline 3rd Quintile & 1 & 7 & 0 & 5 \\
\hline 4th Quintile & 0 & 4 & 0 & 2 \\
\hline 5th Quintile & 0 & 1 & 0 & 0 \\
\hline
\end{tabular}

Notes: Current retirees are born between 1926-39. Boomers are born between 1946-65. Marital status, health status, living arrangements, housing tenure, work status, and income quintile are as of age 67 . Near poverty thresholds are twice the federal poverty thresholds.

Source: Authors' tabulations of MINT (see text for details). 
Table 11. Percent of Older Adults with Per Capita Income Below $45 \%$ of the National Average Wage

\begin{tabular}{|c|c|c|c|c|}
\hline \multirow[b]{2}{*}{ Age 67 Status } & \multicolumn{2}{|c|}{ Current Retirees } & \multicolumn{2}{|c|}{ Boomers } \\
\hline & Age 67 & Age 80 & Age 67 & Age 80 \\
\hline All & $22 \%$ & $30 \%$ & $24 \%$ & $31 \%$ \\
\hline \multicolumn{5}{|l|}{ Gender } \\
\hline Female & 25 & 32 & 26 & 33 \\
\hline Male & 18 & 28 & 20 & 28 \\
\hline \multicolumn{5}{|l|}{ Marital Status } \\
\hline Married & 21 & 28 & 22 & 29 \\
\hline Single & 27 & 36 & 27 & 35 \\
\hline \multicolumn{5}{|l|}{ Race/Ethnicity } \\
\hline Non-Hispanic white & 19 & 26 & 20 & 26 \\
\hline Non-Hispanic black & 40 & 53 & 37 & 47 \\
\hline Hispanic & 40 & 53 & 37 & 50 \\
\hline Asian \& Native American & 32 & 43 & 30 & 36 \\
\hline \multicolumn{5}{|l|}{ Education } \\
\hline High school dropout & 42 & 52 & 54 & 63 \\
\hline High school graduate & 20 & 29 & 26 & 35 \\
\hline College graduate & 9 & 13 & 10 & 14 \\
\hline \multicolumn{5}{|l|}{ Health Status } \\
\hline Healthy & 20 & 28 & 21 & 28 \\
\hline Unhealthy & 29 & 37 & 31 & 39 \\
\hline \multicolumn{5}{|l|}{ Living Arrangements } \\
\hline Alone & 25 & 32 & 26 & 32 \\
\hline Shared & 7 & 22 & 6 & 24 \\
\hline \multicolumn{5}{|l|}{ Housing Tenure } \\
\hline Rent & 41 & 50 & 44 & 50 \\
\hline Own & 19 & 26 & 20 & 28 \\
\hline \multicolumn{5}{|l|}{ Work Status } \\
\hline Not Working & 33 & 36 & 36 & 36 \\
\hline Working & 11 & 25 & 11 & 26 \\
\hline \multicolumn{5}{|l|}{ Labor Force Experience } \\
\hline Less than 20 years & 35 & 41 & 51 & 56 \\
\hline 20 to 29 years & 22 & 30 & 33 & 41 \\
\hline 30 or more year & 15 & 24 & 16 & 24 \\
\hline \multicolumn{5}{|l|}{ Income Quintile } \\
\hline 1st Quintile & 77 & 76 & 80 & 77 \\
\hline 2nd Quintile & 35 & 46 & 37 & 46 \\
\hline 3rd Quintile & 0 & 18 & 1 & 22 \\
\hline 4th Quintile & 0 & 10 & 0 & 9 \\
\hline 5th Quintile & 0 & 2 & 0 & 1 \\
\hline
\end{tabular}

Notes: Current retirees are born between 1926-39. Boomers are born between 1946-65. Marital status, health status, living arrangements, housing tenure, work status, and income quintile are as of age 67.

Source: Authors' tabulations of MINT (see text for details). 
Table 12. Summary Measures of Economic Well-Being for Older Adults at Ages 67 and 80

\begin{tabular}{lccccc}
\hline & \multicolumn{2}{c}{ Current Retirees } & & \multicolumn{2}{c}{ Boomers } \\
\cline { 2 - 3 } \cline { 5 - 6 } & Better Off & Worse Off & & Better Off & Worse Off \\
\hline Family Wealth & $4 \%$ & $92 \%$ & & $2 \%$ & $94 \%$ \\
Family Income & 43 & 42 & & 41 & 44 \\
Poverty & 2 & 2 & & 1 & 1 \\
Near Poverty & 5 & 6 & & 3 & 5 \\
45\% Average Wage & 4 & 12 & & 4 & 11 \\
Replacement Rate & 30 & 59 & & 31 & 57 \\
75\% Replacement Rate & 5 & 16 & & 5 & 17 \\
$50 \%$ Replacement Rate & 3 & 9 & & 3 & 10 \\
\hline
\end{tabular}

Notes: Current retirees are born between 1926-39. Boomers are born between 1946-65. Replacement rates are calculated as the ratio of per capita income (excluding imputed rent and co-resident income) at ages 67 or 80 to shared lifetime earnings. Shared lifetime earnings is the average of wage-indexed shared earnings between ages 22 and 62, where shared earnings are computed by assigning each individual half the total earnings of the couple in the years when the individual is married and his or her own earnings in years when not married.

Individuals are better off (worse off) if their wealth, income, or replacement rates at age 67 increase (decrease) by more than 5 percent at age 80 . And they are better off (worse off) with regard to poverty, near poverty, 45 percent of the national average wage, 75 percent replacement rate, and 50 percent replacement rate if they were below (above) these thresholds at age 67 and above (below) these thresholds at age 80 .

Source: Authors' tabulations of MINT (see text for details). 
Table 13. Characteristics and Median Change in Income (in thousands, \$2005) Among Older Adults Who are Better Off Between Ages 67 and 80

\begin{tabular}{|c|c|c|c|c|c|c|}
\hline \multirow[b]{2}{*}{ Age 67 Status } & \multicolumn{3}{|c|}{ Current Retirees } & \multicolumn{3}{|c|}{ Boomers } \\
\hline & $\begin{array}{c}\text { Percent of } \\
\text { Overall } \\
\text { Sample } \\
\end{array}$ & $\begin{array}{l}\text { Percent of } \\
\text { Better Off }\end{array}$ & $\begin{array}{c}\text { Median } \\
\text { Change in } \\
\text { Income }\end{array}$ & $\begin{array}{c}\text { Percent of } \\
\text { Overall } \\
\text { Sample } \\
\end{array}$ & $\begin{array}{l}\text { Percent of } \\
\text { Better Off }\end{array}$ & $\begin{array}{c}\text { Median } \\
\text { Change in } \\
\text { Income } \\
\end{array}$ \\
\hline All & $100 \%$ & $100 \%$ & $\$ 14$ & $100 \%$ & $100 \%$ & $\$ 17$ \\
\hline \multicolumn{7}{|l|}{ Gender } \\
\hline Female & 62 & 58 & 13 & 62 & 57 & 15 \\
\hline Male & 38 & 42 & 17 & 38 & 43 & 20 \\
\hline \multicolumn{7}{|l|}{ Marital Status } \\
\hline Married & 70 & 68 & 17 & 65 & 60 & 22 \\
\hline Single & 30 & 32 & 10 & 35 & 40 & 12 \\
\hline \multicolumn{7}{|l|}{ Race/Ethnicity } \\
\hline Non-Hispanic white & 83 & 86 & 15 & 76 & 78 & 19 \\
\hline Non-Hispanic black & 8 & 6 & 8 & 9 & 7 & 9 \\
\hline Hispanic & 6 & 5 & 9 & 9 & 8 & 10 \\
\hline Asian \& Native American & 3 & 3 & 12 & 6 & 7 & 18 \\
\hline \multicolumn{7}{|l|}{ Education } \\
\hline High school dropout & 21 & 19 & 9 & 9 & 8 & 9 \\
\hline High school graduate & 59 & 59 & 14 & 60 & 59 & 14 \\
\hline College graduate & 20 & 22 & 23 & 31 & 33 & 29 \\
\hline \multicolumn{7}{|l|}{ Health Status } \\
\hline Healthy & 70 & 71 & 15 & 73 & 73 & 18 \\
\hline Unhealthy & 30 & 29 & 11 & 27 & 27 & 13 \\
\hline \multicolumn{7}{|l|}{ Living Arrangements } \\
\hline Alone & 84 & 84 & 15 & 86 & 87 & 18 \\
\hline Shared & 16 & 16 & 11 & 14 & 13 & 12 \\
\hline \multicolumn{7}{|l|}{ Housing Tenure } \\
\hline Rent & 18 & 18 & 9 & 13 & 17 & 9 \\
\hline Own & 82 & 82 & 16 & 87 & 83 & 19 \\
\hline \multicolumn{7}{|l|}{ Work Status } \\
\hline Not Working & 53 & 65 & 12 & 51 & 69 & 14 \\
\hline Working & 47 & 35 & 20 & 50 & 31 & 24 \\
\hline \multicolumn{7}{|l|}{ Labor Force Experience } \\
\hline Less than 20 years & 30 & 31 & 12 & 14 & 15 & 12 \\
\hline 20 to 29 years & 21 & 21 & 13 & 14 & 14 & 14 \\
\hline 30 or more year & 49 & 49 & 16 & 72 & 71 & 19 \\
\hline \multicolumn{7}{|l|}{ Income Quintile } \\
\hline 1st Quintile & 20 & 22 & 6 & 20 & 24 & 5 \\
\hline 2nd Quintile & 20 & 19 & 9 & 20 & 20 & 10 \\
\hline 3rd Quintile & 20 & 20 & 13 & 20 & 18 & 15 \\
\hline 4th Quintile & 20 & 18 & 17 & 20 & 17 & 21 \\
\hline 5th Quintile & 20 & 21 & 47 & 20 & 21 & 73 \\
\hline
\end{tabular}

Notes: Current retirees are born between 1926-39. Boomers are born between 1946-65. Marital status, health status, living arrangements, housing tenure, work status, and income quintile are as of age 67 . Individuals are better off if their income at age 67 increases by more than 5 percent at age 80.

Source: Authors' tabulations of MINT (see text for details). 
Table 14. Characteristics and Median Change in Income (in thousands, \$2005) Among Older Adults Who are Worse Off Between Ages 67 and 80

\begin{tabular}{|c|c|c|c|c|c|c|}
\hline \multirow[b]{2}{*}{ Age 67 Status } & \multicolumn{3}{|c|}{ Current Retirees } & \multicolumn{3}{|c|}{ Boomers } \\
\hline & $\begin{array}{c}\text { Percent of } \\
\text { Overall } \\
\text { Sample }\end{array}$ & $\begin{array}{l}\text { Percent of } \\
\text { Worse Off }\end{array}$ & $\begin{array}{c}\text { Median } \\
\text { Change in } \\
\text { Income }\end{array}$ & $\begin{array}{c}\text { Percent of } \\
\text { Overall } \\
\text { Sample }\end{array}$ & $\begin{array}{l}\text { Percent of } \\
\text { Worse Off }\end{array}$ & $\begin{array}{c}\text { Median } \\
\text { Change in } \\
\text { Income }\end{array}$ \\
\hline All & $100 \%$ & $100 \%$ & $-\$ 16$ & $100 \%$ & $100 \%$ & $-\$ 23$ \\
\hline \multicolumn{7}{|l|}{ Gender } \\
\hline Female & 62 & 64 & -16 & 62 & 65 & -22 \\
\hline Male & 38 & 36 & -16 & 38 & 35 & -24 \\
\hline \multicolumn{7}{|l|}{ Marital Status } \\
\hline Married & 70 & 78 & -17 & 65 & 76 & -25 \\
\hline Single & 30 & 22 & -11 & 35 & 24 & -17 \\
\hline \multicolumn{7}{|l|}{ Race/Ethnicity } \\
\hline Non-Hispanic white & 83 & 81 & -17 & 76 & 75 & -23 \\
\hline Non-Hispanic black & 8 & 9 & -12 & 9 & 9 & -19 \\
\hline Hispanic & 6 & 7 & -13 & 9 & 10 & -22 \\
\hline Asian \& Native American & 3 & 4 & -18 & 6 & 6 & -26 \\
\hline \multicolumn{7}{|l|}{ Education } \\
\hline High school dropout & 21 & 21 & -11 & 9 & 8 & -14 \\
\hline High school graduate & 59 & 59 & -16 & 60 & 60 & -21 \\
\hline College graduate & 20 & 20 & -24 & 31 & 31 & -32 \\
\hline \multicolumn{7}{|l|}{ Health Status } \\
\hline Healthy & 70 & 70 & -17 & 73 & 74 & -24 \\
\hline Unhealthy & 30 & 30 & -14 & 27 & 26 & -21 \\
\hline \multicolumn{7}{|l|}{ Living Arrangements } \\
\hline Alone & 84 & 81 & -15 & 86 & 83 & -21 \\
\hline Shared & 16 & 19 & -22 & 14 & 17 & -35 \\
\hline \multicolumn{7}{|l|}{ Housing Tenure } \\
\hline Rent & 18 & 16 & -12 & 13 & 11 & -12 \\
\hline Own & 82 & 84 & -17 & 87 & 89 & -25 \\
\hline \multicolumn{7}{|l|}{ Work Status } \\
\hline Not Working & 53 & 35 & -11 & 51 & 28 & -13 \\
\hline Working & 47 & 65 & -19 & 50 & 73 & -27 \\
\hline \multicolumn{7}{|l|}{ Labor Force Experience } \\
\hline Less than 20 years & 30 & 28 & -15 & 14 & 13 & -17 \\
\hline 20 to 29 years & 21 & 21 & -17 & 14 & 14 & -20 \\
\hline 30 or more year & 49 & 50 & -17 & 72 & 73 & -25 \\
\hline \multicolumn{7}{|l|}{ Income Quintile } \\
\hline 1st Quintile & 20 & 12 & -4 & 20 & 10 & -5 \\
\hline 2nd Quintile & 20 & 21 & -10 & 20 & 20 & -13 \\
\hline 3rd Quintile & 20 & 21 & -16 & 20 & 24 & -22 \\
\hline 4th Quintile & 20 & 24 & -24 & 20 & 25 & -35 \\
\hline 5th Quintile & 20 & 22 & -42 & 20 & 22 & -62 \\
\hline
\end{tabular}

Notes: Current retirees are born between 1926-39. Boomers are born between 1946-65. Marital status, health status, living arrangements, housing tenure, work status, and income quintile are as of age 67 . Individuals are worse off if their income at age 67 decreases by more than 5 percent at age 80.

Source: Authors' tabulations of MINT (see text for details). 
Table 15. Summary Measures of Economic Well-Being for Older Adults at Ages 67 and 80, by Marital Status

\begin{tabular}{|c|c|c|c|c|c|c|c|c|}
\hline \multirow{3}{*}{$\begin{array}{l}\text { Age } 67 \text { Status } \\
\text { Age } 80 \text { Status }\end{array}$} & \multicolumn{4}{|c|}{ Current Retirees } & \multicolumn{4}{|c|}{ Boomers } \\
\hline & \multicolumn{2}{|c|}{ Married } & \multicolumn{2}{|c|}{ Single } & \multicolumn{2}{|c|}{ Married } & \multicolumn{2}{|c|}{ Single } \\
\hline & Married & Single & Married & Single & Married & Single & Married & Single \\
\hline Percent of Sample & $54 \%$ & $17 \%$ & $2 \%$ & $28 \%$ & $49 \%$ & $16 \%$ & $2 \%$ & $33 \%$ \\
\hline \multicolumn{9}{|l|}{ Age 67} \\
\hline Median Wealth (in thousands, \$2005) & $\$ 857$ & $\$ 673$ & $\$ 462$ & $\$ 406$ & $\$ 1,177$ & $\$ 922$ & $\$ 671$ & $\$ 583$ \\
\hline Median Income (in thousands, \$2005) & $\$ 61$ & $\$ 52$ & $\$ 30$ & $\$ 29$ & $\$ 84$ & $\$ 68$ & $\$ 45$ & $\$ 40$ \\
\hline Percent in Poverty & $3 \%$ & $4 \%$ & $10 \%$ & $11 \%$ & $2 \%$ & $3 \%$ & $4 \%$ & $6 \%$ \\
\hline Percent in Near Poverty & $11 \%$ & $19 \%$ & $31 \%$ & $36 \%$ & $6 \%$ & $11 \%$ & $16 \%$ & $23 \%$ \\
\hline Percent Below 45\% Average Wage & $18 \%$ & $29 \%$ & $22 \%$ & $27 \%$ & $19 \%$ & $30 \%$ & $20 \%$ & $27 \%$ \\
\hline Median Replacement Rate & $105 \%$ & $101 \%$ & $104 \%$ & $106 \%$ & $94 \%$ & $86 \%$ & $95 \%$ & $94 \%$ \\
\hline Percent Below 75\% Replacement Rate & $28 \%$ & $31 \%$ & $30 \%$ & $29 \%$ & $34 \%$ & $39 \%$ & $33 \%$ & $36 \%$ \\
\hline Percent Below 50\% Replacement Rate & $8 \%$ & $11 \%$ & $9 \%$ & $11 \%$ & $12 \%$ & $15 \%$ & $11 \%$ & $14 \%$ \\
\hline \multicolumn{9}{|l|}{ Age 80} \\
\hline Median Wealth (in thousands, \$2005) & $\$ 570$ & $\$ 380$ & $\$ 371$ & $\$ 267$ & $\$ 802$ & $\$ 510$ & $\$ 556$ & $\$ 409$ \\
\hline Median Income (in thousands, \$2005) & $\$ 60$ & $\$ 33$ & $\$ 49$ & $\$ 28$ & $\$ 77$ & $\$ 44$ & $\$ 64$ & $\$ 37$ \\
\hline Percent in Poverty & $3 \%$ & $6 \%$ & $3 \%$ & $9 \%$ & $2 \%$ & $4 \%$ & $1 \%$ & $5 \%$ \\
\hline Percent in Near Poverty & $12 \%$ & $27 \%$ & $19 \%$ & $36 \%$ & $7 \%$ & $17 \%$ & $6 \%$ & $22 \%$ \\
\hline Percent Below 45\% Average Wage & $28 \%$ & $28 \%$ & $38 \%$ & $36 \%$ & $30 \%$ & $27 \%$ & $36 \%$ & $34 \%$ \\
\hline Median Replacement Rate & $87 \%$ & $105 \%$ & $80 \%$ & $87 \%$ & $75 \%$ & $89 \%$ & $67 \%$ & $78 \%$ \\
\hline Percent Below 75\% Replacement Rate & $42 \%$ & $32 \%$ & $44 \%$ & $41 \%$ & $50 \%$ & $38 \%$ & $58 \%$ & $47 \%$ \\
\hline Percent Below 50\% Replacement Rate & $18 \%$ & $9 \%$ & $19 \%$ & $16 \%$ & $22 \%$ & $11 \%$ & $28 \%$ & $20 \%$ \\
\hline
\end{tabular}

Notes: Current retirees are born between 1926-39. Boomers are born between 1946-65. Replacement rates are calculated as the ratio of per capita income (excluding imputed rent and co-resident income) at ages 67 or 80 to shared lifetime earnings. Shared lifetime earnings is the average of wage-indexed shared earnings between ages 22 and 62 , where shared earnings are computed by assigning each individual half the total earnings of the couple in the years when the individual is married and his or her own earnings in years when not married. The median value is measured as the mean value between the 40th and 60th percentiles of the distribution.

Source: Authors' tabulations of MINT (see text for details). 
Table 16. Summary Measures of Economic Well-Being for Older Adults at Ages 67 and 80, by Health Status

\begin{tabular}{|c|c|c|c|c|c|c|c|c|}
\hline \multirow{3}{*}{$\begin{array}{l}\text { Age } 67 \text { Status } \\
\text { Age } 80 \text { Status }\end{array}$} & \multicolumn{4}{|c|}{ Current Retirees } & \multicolumn{4}{|c|}{ Boomers } \\
\hline & \multicolumn{2}{|c|}{ Healthy } & \multicolumn{2}{|c|}{ Unhealthy } & \multicolumn{2}{|c|}{ Healthy } & \multicolumn{2}{|c|}{ Unhealthy } \\
\hline & Healthy & Unhealthy & Healthy & Unhealthy & Healthy & Unhealthy & Healthy & Unhealthy \\
\hline Percent of Sample & $41 \%$ & $29 \%$ & $15 \%$ & $15 \%$ & $45 \%$ & $28 \%$ & $15 \%$ & $12 \%$ \\
\hline \multicolumn{9}{|l|}{ Age 67} \\
\hline Median Wealth (in thousands, \$2005) & $\$ 838$ & $\$ 601$ & $\$ 649$ & $\$ 478$ & $\$ 1,129$ & $\$ 788$ & $\$ 852$ & $\$ 586$ \\
\hline Median Income (in thousands, \$2005) & $\$ 60$ & $\$ 46$ & $\$ 49$ & $\$ 37$ & $\$ 58$ & $\$ 63$ & $\$ 47$ & $\$ 63$ \\
\hline Percent in Poverty & $4 \%$ & $6 \%$ & $7 \%$ & $10 \%$ & $2 \%$ & $4 \%$ & $4 \%$ & $6 \%$ \\
\hline Percent in Near Poverty & $14 \%$ & $22 \%$ & $22 \%$ & $30 \%$ & $9 \%$ & $14 \%$ & $15 \%$ & $22 \%$ \\
\hline Percent Below 45\% Average Wage & $16 \%$ & $25 \%$ & $25 \%$ & $33 \%$ & $18 \%$ & $26 \%$ & $26 \%$ & $37 \%$ \\
\hline Median Replacement Rate & $113 \%$ & $97 \%$ & $106 \%$ & $97 \%$ & $99 \%$ & $86 \%$ & $95 \%$ & $89 \%$ \\
\hline Percent Below 75\% Replacement Rate & $26 \%$ & $32 \%$ & $28 \%$ & $33 \%$ & $33 \%$ & $40 \%$ & $33 \%$ & $38 \%$ \\
\hline Percent Below 50\% Replacement Rate & $8 \%$ & $11 \%$ & $9 \%$ & $12 \%$ & $12 \%$ & $15 \%$ & $12 \%$ & $14 \%$ \\
\hline \multicolumn{9}{|l|}{ Age 80} \\
\hline Median Wealth (in thousands, \$2005) & $\$ 572$ & $\$ 372$ & $\$ 419$ & $\$ 275$ & $\$ 785$ & $\$ 502$ & $\$ 563$ & $\$ 356$ \\
\hline Median Income (in thousands, \$2005) & $\$ 58$ & $\$ 40$ & $\$ 46$ & $\$ 33$ & $\$ 72$ & $\$ 50$ & $\$ 56$ & $\$ 39$ \\
\hline Percent in Poverty & $3 \%$ & $5 \%$ & $6 \%$ & $8 \%$ & $2 \%$ & $4 \%$ & $4 \%$ & $5 \%$ \\
\hline Percent in Near Poverty & $14 \%$ & $25 \%$ & $24 \%$ & $33 \%$ & $10 \%$ & $15 \%$ & $16 \%$ & $23 \%$ \\
\hline Percent Below 45\% Average Wage & $22 \%$ & $35 \%$ & $32 \%$ & $42 \%$ & $24 \%$ & $35 \%$ & $33 \%$ & $46 \%$ \\
\hline Median Replacement Rate & $99 \%$ & $81 \%$ & $91 \%$ & $81 \%$ & $84 \%$ & $71 \%$ & $81 \%$ & $75 \%$ \\
\hline Percent Below 75\% Replacement Rate & $35 \%$ & $45 \%$ & $38 \%$ & $46 \%$ & $43 \%$ & $54 \%$ & $45 \%$ & $50 \%$ \\
\hline Percent Below 50\% Replacement Rate & $13 \%$ & $19 \%$ & $15 \%$ & $18 \%$ & $17 \%$ & $23 \%$ & $18 \%$ & $21 \%$ \\
\hline
\end{tabular}

Notes: Current retirees are born between 1926-39. Boomers are born between 1946-65. Replacement rates are calculated as the ratio of per capita income (excluding imputed rent and co-resident income) at ages 67 or 80 to shared lifetime earnings. Shared lifetime earnings is the average of wage-indexed shared earnings between ages 22 and 62 , where shared earnings are computed by assigning each individual half the total earnings of the couple in the years when the individual is married and his or her own earnings in years when not married. The median value is measured as the mean value between the 40th and 60th percentiles of the distribution.

Source: Authors' tabulations of MINT (see text for details) 
Table 17. Summary Measures of Economic Well-Being for Older Adults at Ages 67 and 80, by Living Arrangements

\begin{tabular}{|c|c|c|c|c|c|c|c|c|}
\hline \multirow{3}{*}{$\begin{array}{l}\text { Age } 67 \text { Status } \\
\text { Age } 80 \text { Status }\end{array}$} & \multicolumn{4}{|c|}{ Current Retirees } & \multicolumn{4}{|c|}{ Boomers } \\
\hline & \multicolumn{2}{|c|}{ Live Alone } & \multicolumn{2}{|c|}{ Live Shared } & \multicolumn{2}{|c|}{ Live Alone } & \multicolumn{2}{|c|}{ Live Shared } \\
\hline & Alone & Shared & Alone & Shared & Alone & Shared & Alone & Shared \\
\hline Percent of Sample & $79 \%$ & $5 \%$ & $7 \%$ & $9 \%$ & $82 \%$ & $5 \%$ & $6 \%$ & $8 \%$ \\
\hline \multicolumn{9}{|l|}{ Age 67} \\
\hline Median Wealth (in thousands, \$2005) & $\$ 716$ & $\$ 625$ & $\$ 511$ & $\$ 467$ & $\$ 956$ & $\$ 782$ & $\$ 688$ & $\$ 587$ \\
\hline Median Income (in thousands, \$2005) & $\$ 48$ & $\$ 42$ & $\$ 64$ & $\$ 62$ & $\$ 63$ & $\$ 50$ & $\$ 87$ & $\$ 83$ \\
\hline Percent in Poverty & $6 \%$ & $7 \%$ & $3 \%$ & $1 \%$ & $4 \%$ & $6 \%$ & $0 \%$ & $0 \%$ \\
\hline Percent in Near Poverty & $20 \%$ & $25 \%$ & $14 \%$ & $15 \%$ & $13 \%$ & $20 \%$ & $6 \%$ & $7 \%$ \\
\hline Percent Below 45\% Average Wage & $25 \%$ & $27 \%$ & $9 \%$ & $6 \%$ & $26 \%$ & $33 \%$ & $7 \%$ & $6 \%$ \\
\hline Median Replacement Rate & $105 \%$ & $106 \%$ & $103 \%$ & $103 \%$ & $93 \%$ & $87 \%$ & $95 \%$ & $94 \%$ \\
\hline Percent Below 75\% Replacement Rate & $29 \%$ & $26 \%$ & $30 \%$ & $31 \%$ & $35 \%$ & $38 \%$ & $35 \%$ & $35 \%$ \\
\hline Percent Below 50\% Replacement Rate & $9 \%$ & $8 \%$ & $11 \%$ & $11 \%$ & $13 \%$ & $14 \%$ & $13 \%$ & $13 \%$ \\
\hline \multicolumn{9}{|l|}{ Age 80} \\
\hline Median Wealth (in thousands, \$2005) & $\$ 463$ & $\$ 403$ & $\$ 314$ & $\$ 284$ & $\$ 634$ & $\$ 496$ & $\$ 449$ & $\$ 377$ \\
\hline Median Income (in thousands, \$2005) & $\$ 43$ & $\$ 76$ & $\$ 31$ & $\$ 70$ & $\$ 54$ & $\$ 95$ & $\$ 38$ & $\$ 88$ \\
\hline Percent in Poverty & $5 \%$ & $0 \%$ & $11 \%$ & $0 \%$ & $4 \%$ & $0 \%$ & $6 \%$ & $0 \%$ \\
\hline Percent in Near Poverty & $22 \%$ & $7 \%$ & $36 \%$ & $10 \%$ & $14 \%$ & $3 \%$ & $25 \%$ & $6 \%$ \\
\hline Percent Below 45\% Average Wage & $34 \%$ & $4 \%$ & $45 \%$ & $5 \%$ & $34 \%$ & $5 \%$ & $46 \%$ & $8 \%$ \\
\hline Median Replacement Rate & $90 \%$ & $89 \%$ & $87 \%$ & $85 \%$ & $78 \%$ & $74 \%$ & $79 \%$ & $77 \%$ \\
\hline Percent Below 75\% Replacement Rate & $40 \%$ & $40 \%$ & $42 \%$ & $42 \%$ & $47 \%$ & $51 \%$ & $47 \%$ & $48 \%$ \\
\hline Percent Below 50\% Replacement Rate & $15 \%$ & $15 \%$ & $17 \%$ & $18 \%$ & $19 \%$ & $19 \%$ & $21 \%$ & $18 \%$ \\
\hline
\end{tabular}

Notes: Current retirees are born between 1926-39. Boomers are born between 1946-65. Replacement rates are calculated as the ratio of per capita income (excluding imputed rent and co-resident income) at ages 67 or 80 to shared lifetime earnings. Shared lifetime earnings is the average of wage-indexed shared earnings between ages 22 and 62 , where shared earnings are computed by assigning each individual half the total earnings of the couple in the years when the individual is married and his or her own earnings in years when not married. The median value is measured as the mean value between the 40th and 60th percentiles of the distribution.

Source: Authors' tabulations of MINT (see text for details) 
Table 18. Summary Measures of Economic Well-Being for Older Adults at Ages 67 and 80, by Work Status

\begin{tabular}{|c|c|c|c|c|c|c|c|c|}
\hline \multirow{3}{*}{$\begin{array}{l}\text { Age } 67 \text { Status } \\
\text { Age } 80 \text { Status }\end{array}$} & \multicolumn{4}{|c|}{ Current Retirees } & \multicolumn{4}{|c|}{ Boomers } \\
\hline & \multicolumn{2}{|c|}{ Work } & \multicolumn{2}{|c|}{ Not Work } & \multicolumn{2}{|c|}{ Work } & \multicolumn{2}{|c|}{ Not Work } \\
\hline & Work & Not Work & Work & Not Work & Work & Not Work & Work & Not Work \\
\hline Percent of Sample & $8 \%$ & $39 \%$ & $3 \%$ & $50 \%$ & $5 \%$ & $45 \%$ & $2 \%$ & $49 \%$ \\
\hline \multicolumn{9}{|l|}{ Age 67} \\
\hline Median Wealth (in thousands, \$2005) & $\$ 843$ & $\$ 754$ & $\$ 796$ & $\$ 575$ & $\$ 1,110$ & $\$ 1,009$ & $\$ 893$ & $\$ 768$ \\
\hline Median Income (in thousands, \$2005) & $\$ 71$ & $\$ 63$ & $\$ 48$ & $\$ 37$ & $\$ 97$ & $\$ 84$ & $\$ 53$ & $\$ 46$ \\
\hline Percent in Poverty & $0 \%$ & $1 \%$ & $5 \%$ & $10 \%$ & $0 \%$ & $0 \%$ & $5 \%$ & $7 \%$ \\
\hline Percent in Near Poverty & $4 \%$ & $8 \%$ & $19 \%$ & $31 \%$ & $2 \%$ & $3 \%$ & $20 \%$ & $22 \%$ \\
\hline Percent Below 45\% Average Wage & $7 \%$ & $11 \%$ & $22 \%$ & $34 \%$ & $8 \%$ & $11 \%$ & $30 \%$ & $36 \%$ \\
\hline Median Replacement Rate & $118 \%$ & $120 \%$ & $88 \%$ & $90 \%$ & $113 \%$ & $109 \%$ & $79 \%$ & $77 \%$ \\
\hline Percent Below 75\% Replacement Rate & $20 \%$ & $19 \%$ & $35 \%$ & $38 \%$ & $21 \%$ & $23 \%$ & $45 \%$ & $48 \%$ \\
\hline Percent Below 50\% Replacement Rate & $4 \%$ & $5 \%$ & $14 \%$ & $14 \%$ & $7 \%$ & $6 \%$ & $21 \%$ & $19 \%$ \\
\hline \multicolumn{9}{|l|}{ Change at Age 80} \\
\hline Median Wealth (in thousands, \$2005) & $\$ 562$ & $\$ 490$ & $\$ 533$ & $\$ 359$ & $\$ 755$ & $\$ 668$ & $\$ 599$ & $\$ 503$ \\
\hline Median Income (in thousands, \$2005) & $\$ 85$ & $\$ 48$ & $\$ 76$ & $\$ 37$ & $\$ 108$ & $\$ 63$ & $\$ 89$ & $\$ 48$ \\
\hline Percent in Poverty & $0 \%$ & $2 \%$ & $3 \%$ & $8 \%$ & $1 \%$ & $1 \%$ & $3 \%$ & $5 \%$ \\
\hline Percent in Near Poverty & $2 \%$ & $16 \%$ & $6 \%$ & $30 \%$ & $2 \%$ & $9 \%$ & $5 \%$ & $20 \%$ \\
\hline Percent Below 45\% Average Wage & $9 \%$ & $28 \%$ & $11 \%$ & $37 \%$ & $9 \%$ & $28 \%$ & $17 \%$ & $37 \%$ \\
\hline Median Replacement Rate & $121 \%$ & $81 \%$ & $135 \%$ & $89 \%$ & $115 \%$ & $73 \%$ & $129 \%$ & $80 \%$ \\
\hline Percent Below 75\% Replacement Rate & $21 \%$ & $45 \%$ & $16 \%$ & $41 \%$ & $22 \%$ & $53 \%$ & $23 \%$ & $46 \%$ \\
\hline Percent Below 50\% Replacement Rate & $6 \%$ & $19 \%$ & $4 \%$ & $16 \%$ & $7 \%$ & $21 \%$ & $8 \%$ & $19 \%$ \\
\hline
\end{tabular}

Notes: Current retirees are born between 1926-39. Boomers are born between 1946-65. Replacement rates are calculated as the ratio of per capita income (excluding imputed rent and co-resident income) at ages 67 or 80 to shared lifetime earnings. Shared lifetime earnings is the average of wage-indexed shared earnings between ages 22 and 62 , where shared earnings are computed by assigning each individual half the total earnings of the couple in the years when the individual is married and his or her own earnings in years when not married. The median value is measured as the mean value between the 40th and 60th percentiles of the distribution.

Source: Authors' tabulations of MINT (see text for details) 


\section{RECENT WORKING PAPERS FROM THE}

\section{CENTER FOR RETIREMENT RESEARCH AT BOSTON COLLEGE}

International Investment for Retirement Savers: Historical Evidence on Risk and Returns

Gary Burtless, February 2007

Job Changes at Older Ages: Effects on Wages, Benefits, and other Job Attributes

Richard W. Johnson and Janette Kawachi, February 2007

Cross-National Comparison of Income and Wealth Status in Retirement: First Results from the Luxembourg Wealth Study (LWS)

Eva Sierminska, Andrea Brandolini and Timothy M. Smeeding, February 2007

Saving and Demographic Change: The Global Dimension

Barry Bosworth and Gabriel Chodorow-Reich, February 2007

The Repeal of the Retirement Earnings Test and the Labor Supply of Older Men Gary V. Engelhardt and Anil Kumar, February 2007

Persistence in Labor Supply and the Response to the Social Security Earnings Test Leora Friedberg and Anthony Webb, December 2006

Annuitized Wealth and Consumption at Older Ages

Barbara A. Butrica and Gordon B.T. Mermin, December 2006

Risk and Reward of International Investing for U.S. Retirement Savers:

Historical Evidence

Gary Burtless, December 2006

State Age Protection Laws and the Age Discrimination in Employment Act Joanna Lahey, November 2006

Age, Women, and Hiring: An Experimental Study

Joanna Lahey, November 2006

Optimal Retirement Asset Decumulation Strategies: The Impact of Housing Wealth Anthony Webb, Robert Triest, and Wei Sun, November 2006

All working papers are available on the Center for Retirement Research website (http://www.bc.edu/crr) and can be requested by e-mail (crr@bc.edu) or phone (617-552-1762). 